\title{
Imidacloprid Bark Treatment for Hemlock Woolly Adelgid (Adelges tsugae)
}

\author{
Matthew D Quinterno
}

Follow this and additional works at: https://researchrepository.wvu.edu/etd

\section{Recommended Citation}

Quinterno, Matthew D, "Imidacloprid Bark Treatment for Hemlock Woolly Adelgid (Adelges tsugae)" (2018). Graduate Theses, Dissertations, and Problem Reports. 7234.

https://researchrepository.wvu.edu/etd/7234

This Thesis is protected by copyright and/or related rights. It has been brought to you by the The Research Repository @ WVU with permission from the rights-holder(s). You are free to use this Thesis in any way that is permitted by the copyright and related rights legislation that applies to your use. For other uses you must obtain permission from the rights-holder(s) directly, unless additional rights are indicated by a Creative Commons license in the record and/ or on the work itself. This Thesis has been accepted for inclusion in WVU Graduate Theses, Dissertations, and Problem Reports collection by an authorized administrator of The Research Repository @ WVU. For more information, please contact researchrepository@mail.wvu.edu. 


\title{
Imidacloprid Bark Treatment \\ for Hemlock Woolly Adelgid (Adelges tsugae)
}

\author{
Matthew D. Quinterno \\ Thesis submitted \\ to the Davis College of Agriculture, Natural Resources and Design \\ at West Virginia University \\ in partial fulfillment of the requirements for the degree of \\ Master of Science in \\ Forest Resources Management \\ Gregory Dahle, Ph.D., Chair \\ Kathyrn Gazal, Ph.D. \\ Anand Persad, Ph.D. \\ Yong-Lak Park, Ph.D. \\ Division of Plant and Soil Sciences \\ Morgantown, West Virginia \\ 2018
}

Keywords: arboriculture, imidacloprid, bark application, basal-bark application, bark sprays, hemlock woolly adelgid, IPM

Copyright 2018 Matthew Quinterno 


\begin{abstract}
Imidacloprid Bark Treatment for Hemlock Woolly Adelgid (Adelges tsugae)

Matthew D. Quinterno
\end{abstract}

Since its discovery in the United States during the 1950s, Hemlock Wooly Adelgid (Adelgis tsugae Annand) has touched much of Eastern hemlock's (Tsugae canadensis L. Carrière) native range. Arborists have successfully handled this pest using either contact or systemic treatments. One of these treatments, imidacloprid, has often been used as a soil treatment. Due to its dependancy on water uptake by the tree, the insecticide sits in the soil for prolonged periods of time posing a threat to aquatic invertebrae and our drinking water. Imidacloprid has been labeled for use as a basal bark spray to control HWA, however limited information regarding its efficacy is avilable. Basal bark applications stand to serve technicians as a new tool by reducing translocation time, labor costs, material costs, eliminate tree wounding, minimize liability, and exposure to the environmen.

By comparing bark sprays to soil application this project will determine: 1.) if imidacloprid or olefin concentrations are similar between bark applications and soil application 2.) whether high or low labeled rates influence the concentration of imidacloprid or olefin compounds 3.) if bark applications are as effective as soil applications at reducing A. tsugae populations 4.) the neccessity of an adjuvant (Pentra-bark $\left.{ }^{\circledR}\right)$ and 5.) the feasibility of the application method. Determination was conducted by treating fifty-six trees by soil injection, basal bark application, or basal bark plus an adjuvant. These treatments were replicated at $0.67 \mathrm{~g} / 2.5 \mathrm{~cm} \mathrm{DBH}$ and $1.37 \mathrm{~g} / \mathrm{cm} \mathrm{DBH}$, the low and high labeled rates. This experiment, arranged in a $3 \times 2$ factorial fashion, also included a control.

Tissue concentrations of imidacloprid and olefin were analyzed by LC/MS/MS while biological efficacy was assessed through the collection of three population samples and the use of Abott's mortality correction formula. Orthognal contrasts were used for all analyses. Imidacloprid tissue results suggest no significant differences existed between soil and bark applications $(\mathrm{P}=0.0789)$, bark applications and bark + Pentra-bark ${ }^{\circledR}$ applications $(\mathrm{P}=0.8358)$, and low and high labeled rates $(\mathrm{P}=0.1181)$. Olefin concentrations suggest no significant differences existed between soil and bark applications $(\mathrm{P}=0.2121)$, bark applications and bark + Pentra-bark ${ }^{\circledR}$ applications $(\mathrm{P}=0.7721)$, and low and high labeled rates $(\mathrm{P}=0.5013)$. Biological efficacy results suggest that significant differences existed only between the bark applications and soil applications six months post treatment $(\mathrm{P}=0.0384)$ but not at eleven months $(\mathrm{P}=$ $0.0855)$. Financial results indicate no signficant difference was found between soil and bark applications $(\mathrm{P}=0.1194)$ and between bark applications bark + Pentra-bark ${ }^{\circledR}$ applications $(\mathrm{P}=$ $0.1009)$, while signficant differences existed between low and high labeled rates $(\mathrm{P}=0.0004)$. 


\section{Dedication}

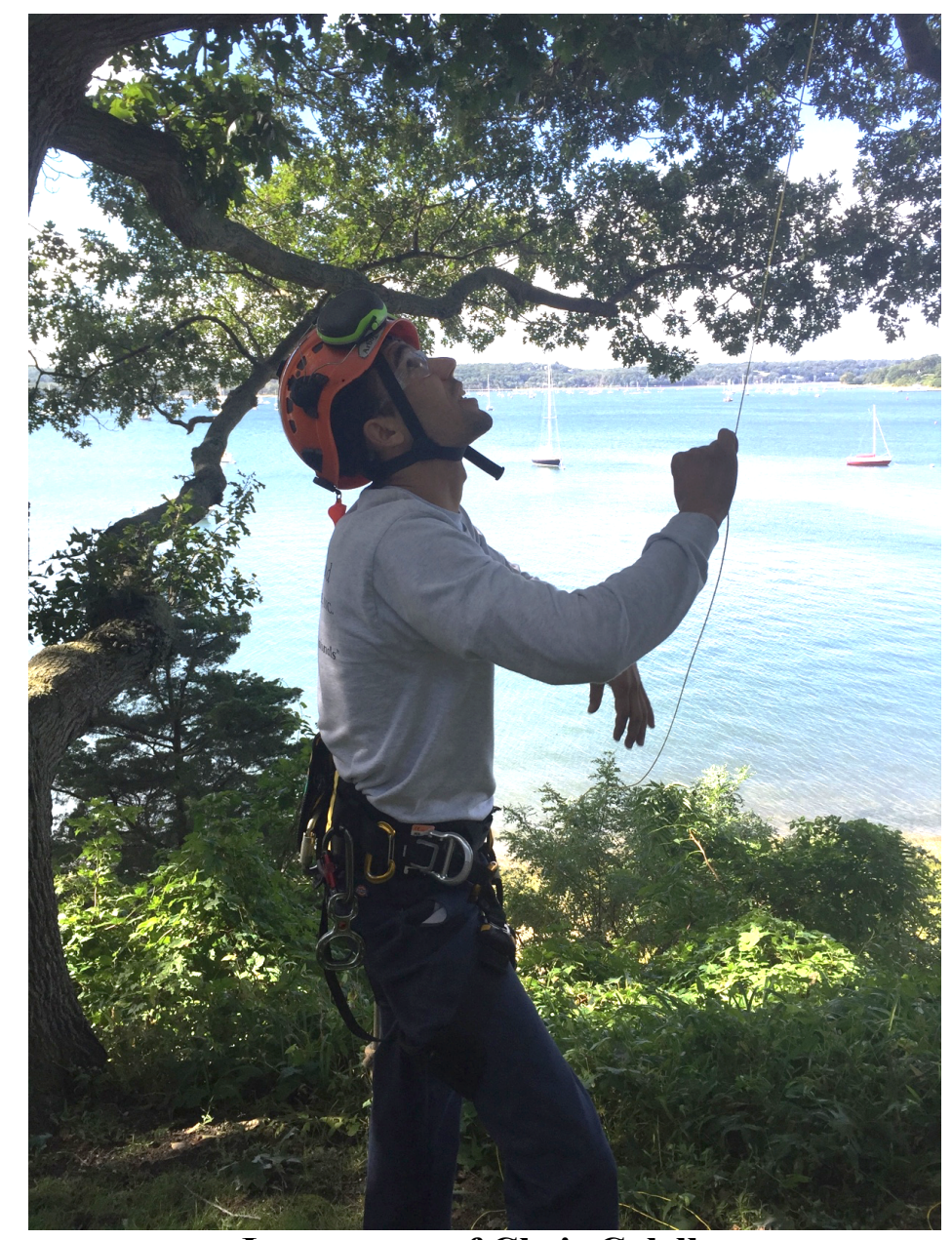

In memory of Chris Colella.

1989-2015

May your enthusiasm, curiosity, and passion for trees never be forgotten. 


\section{Acknowledgements}

Many people have graciously aided me along this project and I am thankful to all of them. I would like to begin with Dr. Michael Coyle to whom I owe much gratitude. Without his guideance from youth to adulthood, my life would be much different. It was through his constant encouragement and patience by which I returned to school and this project was concieved. My deepest thanks belong to my wife Elizabeth, who did not object to moving away from the home we made back to the Mid-Atlantic. Without her willingness to do so, this project would not be possible.

Throughout my nine years in the Army National Guard, I have made several friends that have become family. First Lieutenant Brian Elliot and Staff Sergeant Guercy Dominique are two of these, and without their appearance in the nick of time, my move to West Virginia University would have been waylaid.

While initiating this project, Aaron Dickinson of Rainbow Treecare Scientific, Mike Raupp of the University of Maryland, and Dan Gilren of Cornell University spent their valuable time thoughtfully answering my questions and providing guidance that pointed me in the right direction to developing a research topic. With a topic established, Biff Thompson of the Maryland Department of Conservation and Natural Resources aided me in the location of a suitable site.

With a project established, Dr. Elizabeth Benton of the University of Tennessee, Dr. Rick Turcotte of the U.S. Forest Service, Dr. Anthony Lagalante of Villanova University, and Dr. Richard Cowles of the Connecticut Agrigulture station were all very kind in answering questions regarding imidacloprid despite being associated only by a common area of research. Dr. 
Matthew Kasson and the members of his lab at West Virginia University were generous enough to share their facility, their company, and their knowledge as I prepared and counted samples.

As I completed the project, John Seifer of the Davey Research Institute and Dr. Ida Holásková were both invaluable. John aided me in my last journey to the field while Ida of West Virginia University was crucial in running my statistical analyses.

Throughout the entire process, my committee patiently guided me along through completing this degree. Dr. Gregory Dahle, Dr. Kathryn Gazal, and Dr. Yong-Lak Park of West Virginia University as well as Dr. Anand Persad of the Davey Research Institute not only shared their time, advice, attention, and expertise, but their resources as well. These resources made my time both in the field and in the lab easier and more enjoyable.

Lastly I would like to thank those closest to me. My thoughts go out to my parents, Barbara and John, for instilling the value of education in all their children and to my brother, John, who who took an interest in the project and offered invaluble thoughts for improving the text. I owe a large thanks to my sister and brother-in-law, Barbara and Steve. They were always present as Elizabeth and myself began our life together. The time spent with them and their three beautiful girls is truly cherished. 


\section{Table of Contents}

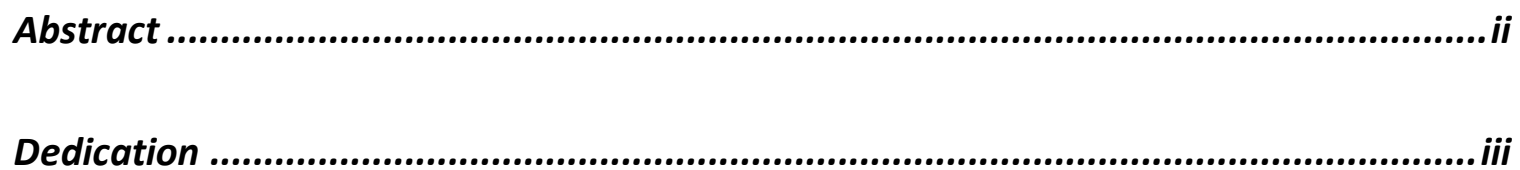

Acknowledgements ....................................................................................

Chapter 1: Introduction.....................................................................................

Chapter 2: Literature Review .............................................................................4

Chapter 3: Comparison of Biological \& Financial Efficacy of Bark Treatments ............. 35

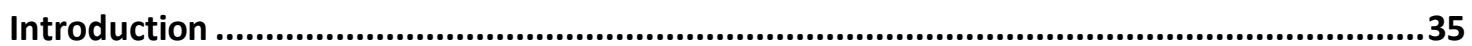

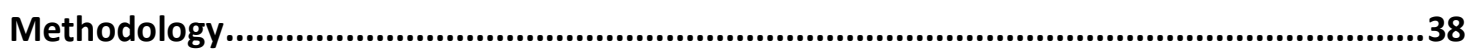

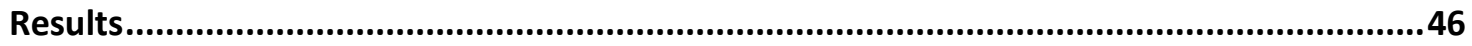

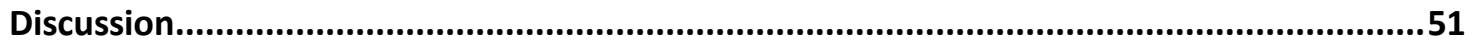

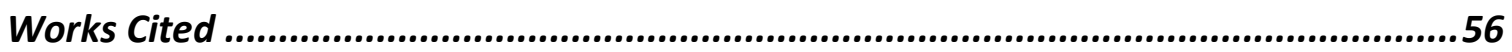

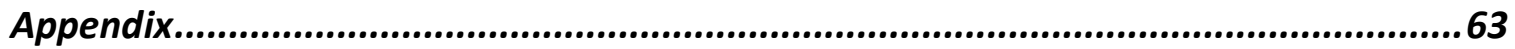

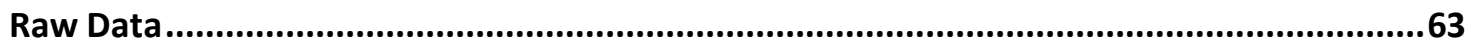

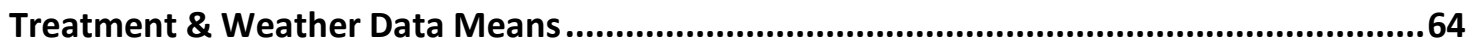

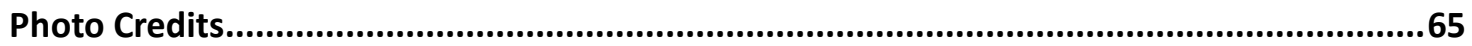




\section{List of Figures}

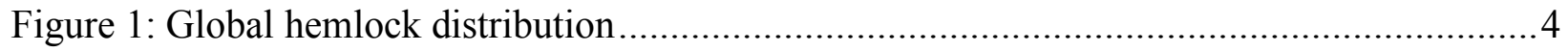

Figure 2: Global HWA distribution..................................................

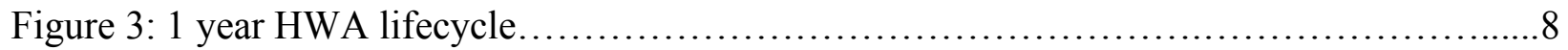

Figure 4: Lifecycle details..................................................... 11

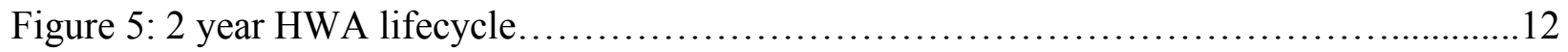

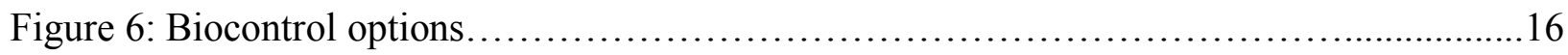

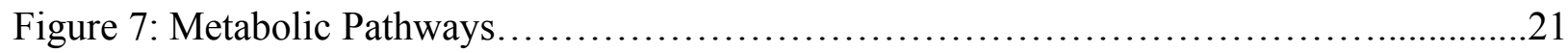

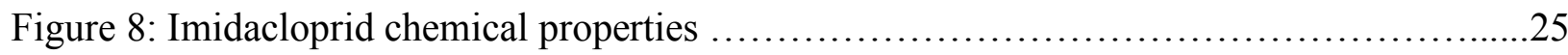

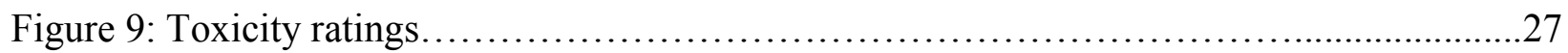

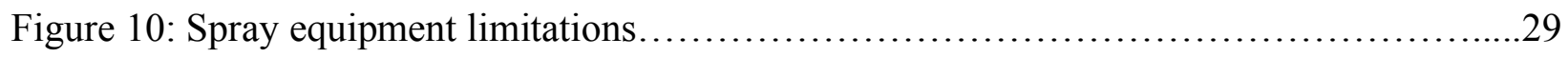

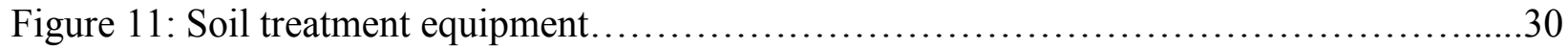

Figure 12: Trunk injection equipment................................................

Figure 13:Backpack sprayer.....................................................

Figure 14: Equipment used.................................................... 41

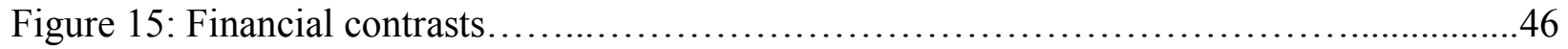

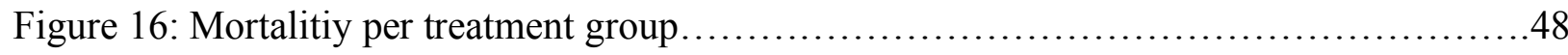

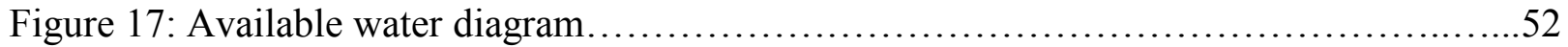

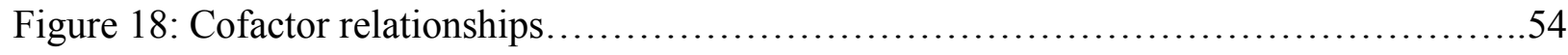




\section{List of Tables}

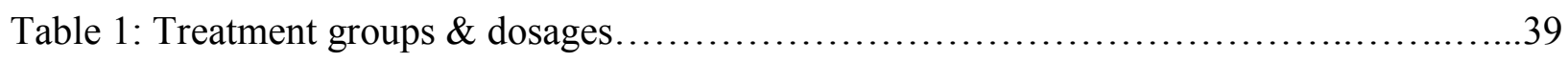

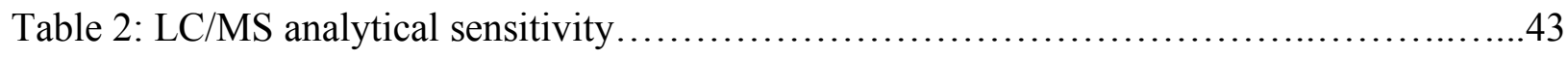

Table 3: Imidacloprid \& olefin concentration contrasts..................................46

Table 4: Live adult contrasts................................................... 47

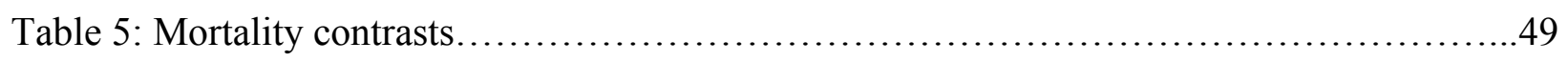

Table 6: Financial Contrasts......................................................49

Table 7: Monthly average soil moisture.............................................. 50 


\section{Chapter 1: Introduction}

Adelges tsugae Annand (Hempitera: Adelgidae), otherwise known as hemlock woolly adelgid or HWA for short, arrived on the East coast of the United States roughly seventy years ago. This invasive pest has killed enough eastern (Tsuga canadensis (L.) Carrière) and Carolina hemlocks (Tsuga caroliniana Englemann) for the trees to be declared as "near threatened", only two levels above endangered, by the International Union for the Conservation of Nature (IUCN 2011). Due to the vast geographic range of its host species, land managers have had a hard time combating HWA.

Over the decades, a handful of chemical tools have slowly emerged making it easier for arborists and pesticide applicators to control adelgid on a limited scale. The interaction of a product's chemical properties and federally approved application methods gives a product particular characteristics. These characteristics may make one product more favorable than another depending upon the environment in which applications are being made. With a limited number of products and application methods approved for HWA treatment, expanding either would benefit not only arborists, but land managers of all sorts.

The insecticide known as imidacloprid shows potential in providing arborists another way of combating HWA. It has been used in HWA treatments for several decades and its properties, that also make it the most popular pesticide in the world, may allow it to be applied in ways that have only recently been permitted (Elbert et al. 2008). First, it is systemic, meaning it can be internalized by a plant where it can lie to kill unsuspecting insects that feed upon that plant. Additionally, this insecticide possesses a long-lasting residue and is quite inexpensive. 
These properties make it perfect for treating HWA; however the approved application methods are where it falls short.

Currently soil drenches, soil injections, trunk injections, and foliar sprays are the allowed methods. Soil injections or soil drenches both require equipment, such as spray rigs or specialized injectors. Trunk injections also require equipment and wound the tree. Likewise, foliar applications require spray rigs and heavy hoses that may limit how high they can reach. The fine mist produced from high pressure hoses creates the potential for chemical to drift off the intended target and perhaps onto adjacent properties. This uneccsarily exposes the environment to chemicals and the applicators liability.

Having used many products and application methods as a professional arborist, the frequency of HWA infestations left me with a need for a method that was easy to carry and quick to apply. Products applied to the bark meet these needs as they are transported and applied through a backpack sprayer, a conveniently carried apparatus. While imidacloprid is not labeled for bark applications, even for the treatment of other insects, it does belong to a class of chemical insecticides known as neonicotinoids, of which, several are labeled for basal bark applications.

Evidence suggests that basal bark applications may not only work, but technicians and chemical manufacturesrs are interested in this method as well. This may especially be the case in Nassau and Suffolk counties of New York where soil injections are prohibited. Such evidence includes a 2(ee) exemption made by the New York Department of Environmental Conservation for bark applications of particular imidacloprid formulations. 


\section{Research Objectives}

The overarching goal of this research project was to examine the plausibility of adding another tool by which pesticide technicians can combat HWA. This will be accomplished by determining:

- Whether imidacloprid can systemically penetrate bark on its own

- If a particular labeled rate is required to penetrate bark

- If an adjuvant is required to penetrate bark

- Imidacloprid's effectiveness against HWA.

- By performing a comparative financial analysis between imidacloprid bark applications and soil injections.

\section{Hypothesis}

After reviewing pertinent literature, the most likely outcome of this experiment appears to be:

- imidacloprid will penetrate bark on its own

- adjuvant is not needed for bark penetration

- labeled rates will have an impact on penetration

- adelgid reduction will be comparable to soil injections

- the overall cost will be similar to that of soil injections 


\section{Chapter 2: Literature Review}

\section{A. Hemlock Distribution}

Approximately ten species constitute the genus Tsuga within the Pinaceae family. The number of species classified as being within this genus has fluctuated over time (Dirr 1998; Havill, Vieira, and Salom 2014). Four of these are native to North America: Carolina hemlock (Tsuga caroliniana), eastern hemlock (T. canadensis), mountain hemlock (T. mertensiana), and western hemlock (T. heterophylla). Of these four, eastern and Carolina hemlock are native to the Eastern seaboard, while mountain and western hemlock reside on the Western seaboard (Joseph et al. 2011). Global distribution is illustrated in Figure 1.

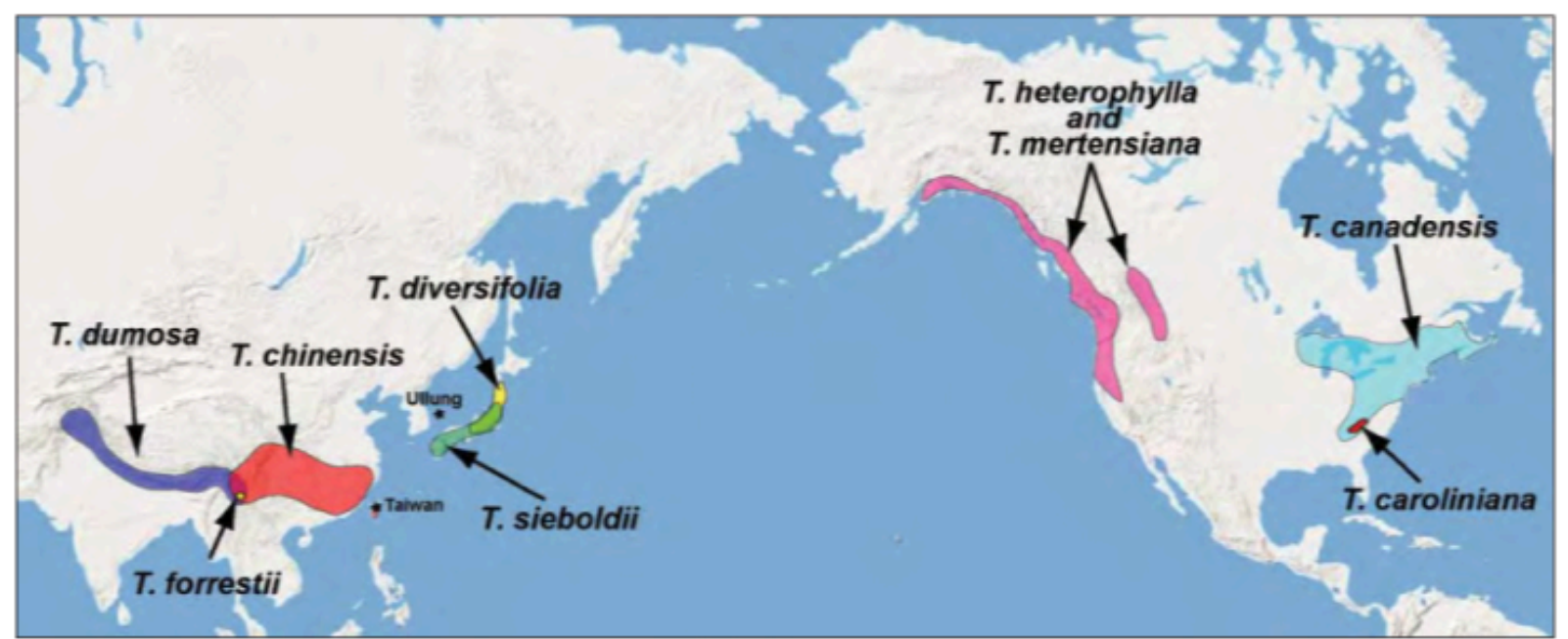

Figure 1: Global distribution of all hemlock species. T. canadensis, the subject of our focus, resides on the North American Eastern Seaboard (Nathan Havill, USDA Forest Service, Northern Research Station). Over time, the number of species considered apart of this genus has fluctuated. 


\section{Eastern Hemlock}

As the most populus hemlock species of Eastern North America, T. canadensis will be the focus of this thesis. This slow growing and shade tolerant conifer is a frequent landscape tree in the Eastern U.S. urban forest (Webb et al. 2003). Maturity is reached between 250 and 300 years of age while some specimens have been found to reach an age of 900 years. In forest stands they may spend 25 - 400 years in the understory (Burns and Barbara 1990).

Trees are typically $30 \mathrm{~m}$ tall, with a broad and conical crown. The branches tend to drop at the ends causing a "feathery" appearance. Their needles are evergreen, about $20 \mathrm{~mm}$ long and flat. Needles' top surfaces possesses a distinct green sheen while the bottom sports two broad white stomatal bands. Seed cones are roughly $2 \mathrm{~cm}$ long, ovoid, and hang near the branch tips. Cone production begins at about fifteen years of age (Guy Nesom 2000).

Ovulate and staminate cones of eastern hemlock are present on separate clusters of the same branch, making T. canadensis monoecious. Pollination occurs between late April and early June while fertilization takes roughly six weeks. Both pollen and seeds are wind dispersed. Dispersal typically occurs from mid - October through winter. Cones open in mid-October releasing seeds. Of all the conifers in the Eastern U.S., eastern hemlock produces the most cones. While this is the case, germination rates are estimated at less than $25 \%$ percent (Burns and Barbara 1990).

In the urban environment, eastern hemlock has been used as a specimen, screen, or group planting. Due to its crown density, hemlock is often sheared to form an evergreen hedge. Its popularity has brought on the production of several cultivars for dwarf, compact, and weeping qualities (Dirr 1998). 
Eastern hemlock grows from Nova Scotia to Minnesota, South along the mountains to Alabama and Georgia. At roughly 1,000 feet in elevation it begins to appear and at 2,000 feet its presence is abundant. It prefers slopes and anywhere drainage is decent (Dirr 1998). Meanwhile Carolina hemlock occurs in isolated pockets in the states of Virginia, North Carolina, South Carolina, Tennessee, and Georgia (Burns and Barbara 1990).

\section{B. Hemlock Woolly Adelgid}

HWA is an insect belonging to the order Hemiptera. Of all the hemipteran species, it is closely related to true aphids (Aphididae) and phylloxerans (Phylloxeridae), as it shares similar characteristics such as a complex life cycle et. al 2014). It resides on nine of the ten hemlock species worldwide; however, it is only a significant pest to the two species residing on North America's East Coast: eastern and Carolina hemlock (Figure 2). Prior to its discovery on these, it had been found across Japan, mainland Asia, and the North American West Coast (Havill et. al 2014).

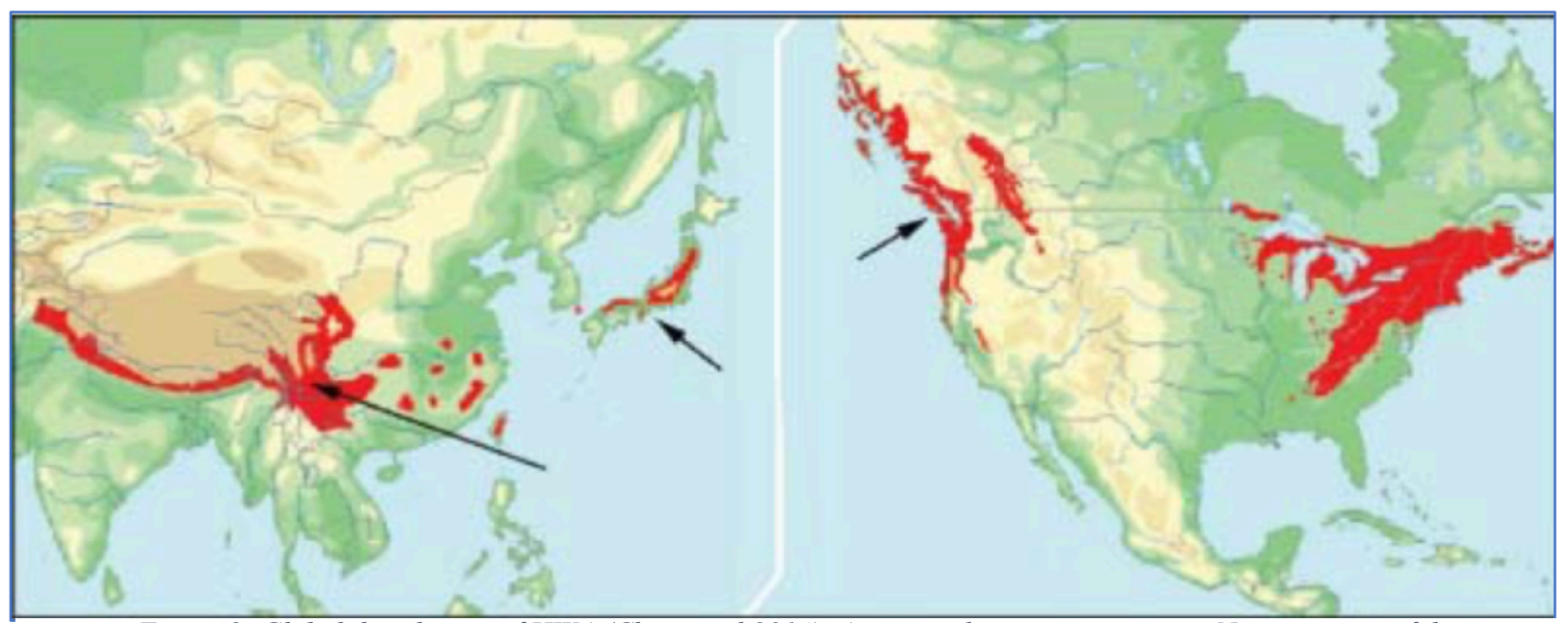

Figure 2: Global distribution of HWA (Chea et. al 2014). Arrows indicate native ranges. Native ranges of the insect coincide with the the species of hemlocks not found on North America's East Coast. DNA evidence suggests the HWA populations that reached the Northeast came from Japan and not North America's Pacific Coast. 
Its introduction to the Eastern seaboard can be traced to Richmond, Virginia, as museum specimens have been found here dating back to 1951. Arrival in Richmond is believed to be prior to this date and most likely directly from southern Japan, not from the American West Coast as DNA evidence suggests (McClure 1987; Havill et al. 2006). The global population of HWA is comprised of five genotypes: four native to Asia and one native to Western North America. Estimates state HWA roughly occupies half of the eastern hemlock range (Cheah et al. 2004). The expanse has risen North; however, as it reaches cooler climates the spread has slowed. It is believed that the lineage present in eastern North America is adapted to the lower elevations of Southern Japan and may lack a cold tolerance (McClure 1987; M. S. McClure and Cheah 2002). However, research is calling attention to a possible Northern progression due to climate change and the possibility this pest is adapting to the cold conditions in its new range (McClure and Cheah 2002).

\section{Adelgid Life Cycle}

The HWA life cycle is complex, as it can reproduce both sexually and asexually, has winged and non-winged forms, can utilize multiple hosts, and possesses multiple generations in a single year. In its native region, HWA alternates between two hosts (Tsuga sieboldii and Picea Torano) where these two species coexist. Of these hosts, T. sieboldii is considered the primary, as it is the host on which sexual reproduction takes place. Between both hosts, five generations occur over the course of two years. 
In North America, populations can survive solely on the alternate host: the hosts being $T$. heterophylla and T. mertensiana in the West and T. canadensis and T. caroliniana in the East Thus, the populations here experience a truncated lifecycle. Each year, a winter and spring generation occur on the alternate host, the first is termed the "sistens" and the second is termed "progrediens". These Latin terms mean "to pause" and "to proceed," respectively, as the sistens, or winter generation, experience an aestivation period (Figure 3). This suspense of physical development is to protect itself from the hot summer temperatures and, therefore, the winter generation is much longer. In North America, the sistens generation develops from June through March, while the progrediens develops much more quickly between the months of March to June. Overlap of these generations is common due to the long period of egg laying and hatching. Ovisacs of the winter generation hold roughly 300 eggs, while the spring ovisacs hold around 20 to 75 (Chowdhury 2002).

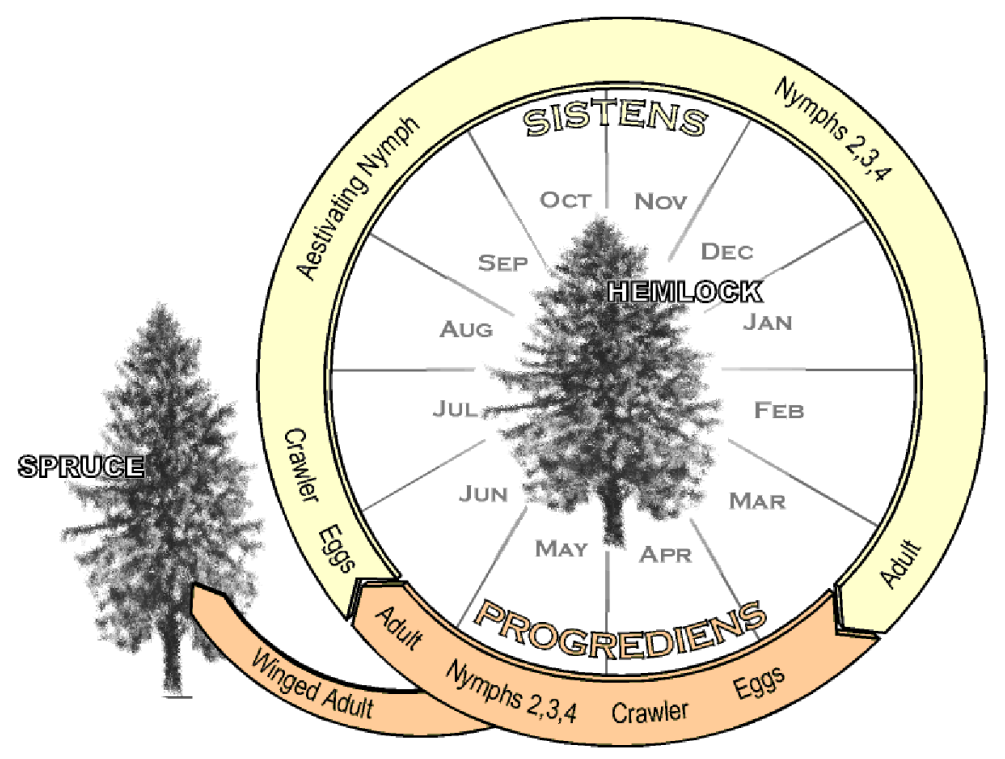

Figure 3: HWA Lifecycle. The lifecycle is quite complext as two generations occur each year. Such a lifecycle is described as being "bivoltine", and consists of a progrediens and sistens generation, more commonly called the "spring/summer generations". While this may be the case, generations are not well aligned with those seasons and overlap does occour. Figure fromf Ward et al. 2004 
From the eggs (Figure 4A) of both generations, first instars known as crawlers emerge (Figures 4B \& 4C). As the only mobile stage, crawlers search for suitable feeding sites on the underside of the needles. At a size of $0.3 \mathrm{~mm}$ they may be dispersed by wind or animals. These reddish-brown crawlers are also the most unprotected stage as they lack their "woolly" covering for which they are named. Once a crawler settles, it does so permanently as becoming a second instar (Figure 4D). At this point, the insect molts, changes from reddish brown, and becomes black, possessesing a white waxy "halo" around its perimeter. It will retain these characteristics as it progresses into third and fourth instars (Figure 4E). When reaching maturity, a thick waxy woolly covering is formed (Figure 4F, 4G, \& 4H). This covering is thought to serve as protection from desiccation and predators as it contains anthraquiones, biological compounds that serve as predator deterrents (Havil 2014, McClure 1987, Jones 2014).

Adults of the progrediens generation may be winged. These winged "sexuparae" (Figure 4I) consist of both sexes and fly in search of the primary host. Research of roughly a dozen spruce species in North America has found winged adults can find, colonize, and lay eggs in certain instances; however, the nymphs have not survived. Hence, it is considered that most of the individuals of HWA in North America are produced from asexual reproduction (McClure 1987).

In adelgids' native region where a primary host can be found, another three generations flourish (Figure 5). Eggs laid by sexuparae produce a short sexual generation. Upon the conclusion of mating, females lay a single large egg that later develops into an asexual female, known as a fundatrix. Females overwinter in close proximity to where they feed upon the buds through the spring, forming a gall (Figure 4J). They lay many eggs that later hatch into crawlers, known as gallicole. Nymphal gallicole stages crawl into the gall where they feed until maturity. 
They then emerge and fly back to the hemlock, drawing a conclusion to the five developmental stages and yearlong lifecycle on spruce (Cheah et al. 2004). 

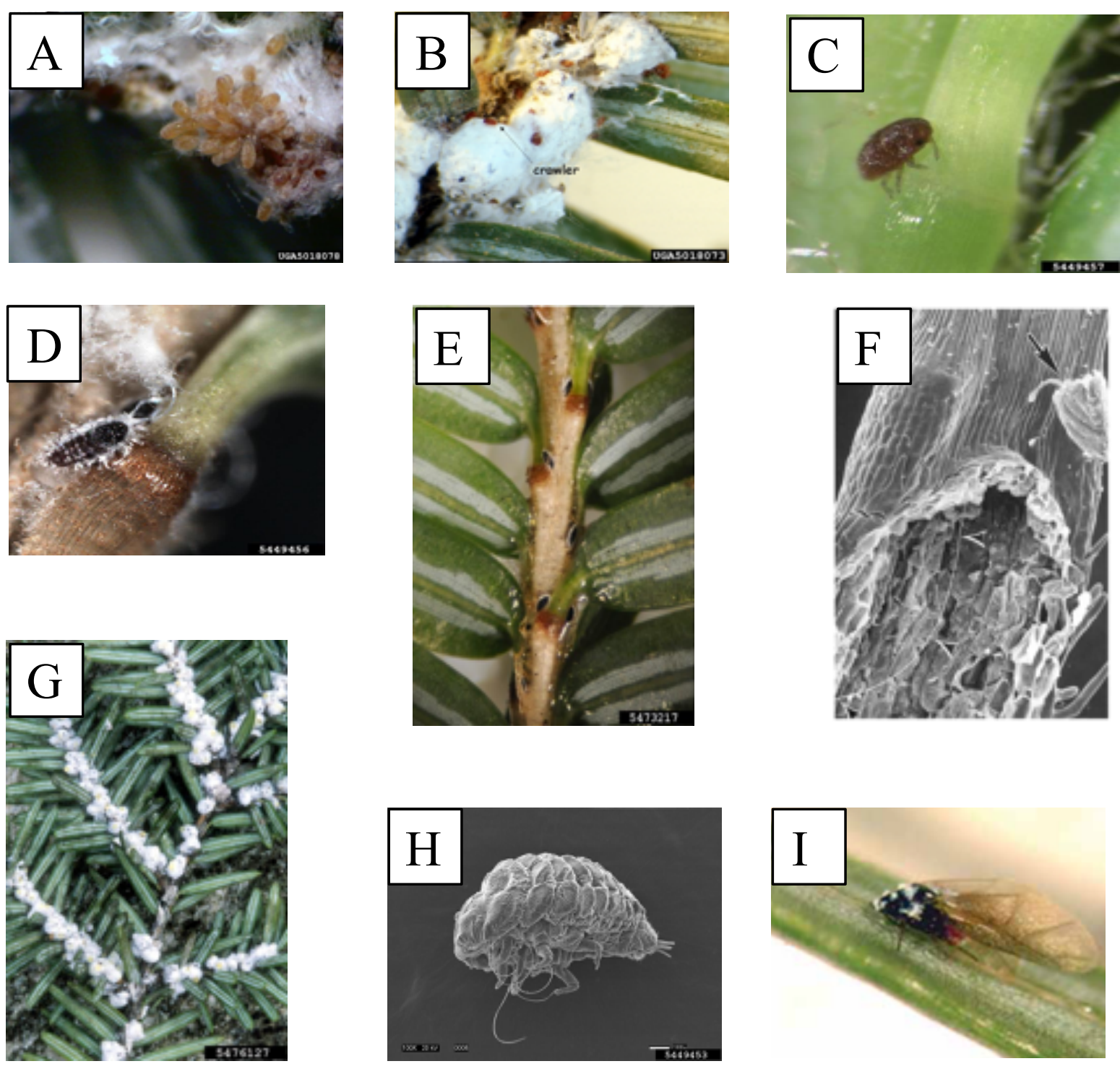

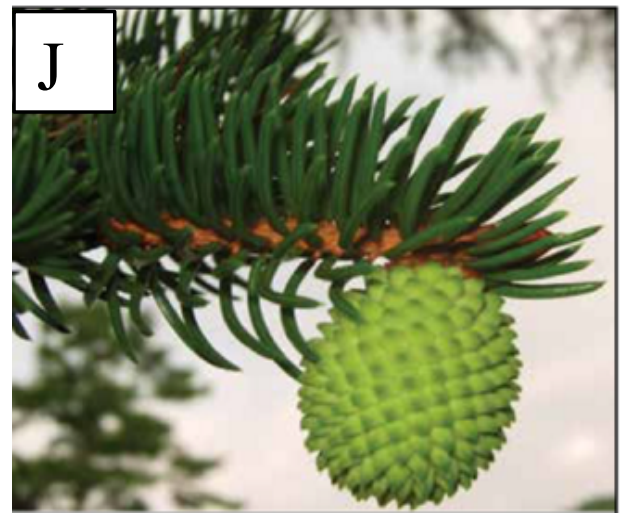

Figure 4: Various stages and anatomical features of HWA. See descriptions to right. Images I \& $J$ are courtsey of Nathan Havil, USFS. A-H are courstsey www.forestryimages.org Reference numbers can be found in lower right corner of the photo.
A. Eggs

B. $1^{\text {st }}$ instar crawlers; note thesize

C. $1^{\text {st }}$ instar crawlers; note the distinguishing color

D. Nymphs (2 ${ }^{\text {nd }}$ instar) feeding at needle base

E. $2^{\text {nd }}$ instar nymphs lined along bottom of branch

F. Needle cross section of adelgidfeeding. The arrows point out the adult and the long stylet

G. White woolly ovisacs give a cotton ball like appearance

H. Mature adelgid with coiled stylet

I. $\quad$ Winged sexupare

J. Gall created by fundatrix on P. Torano 


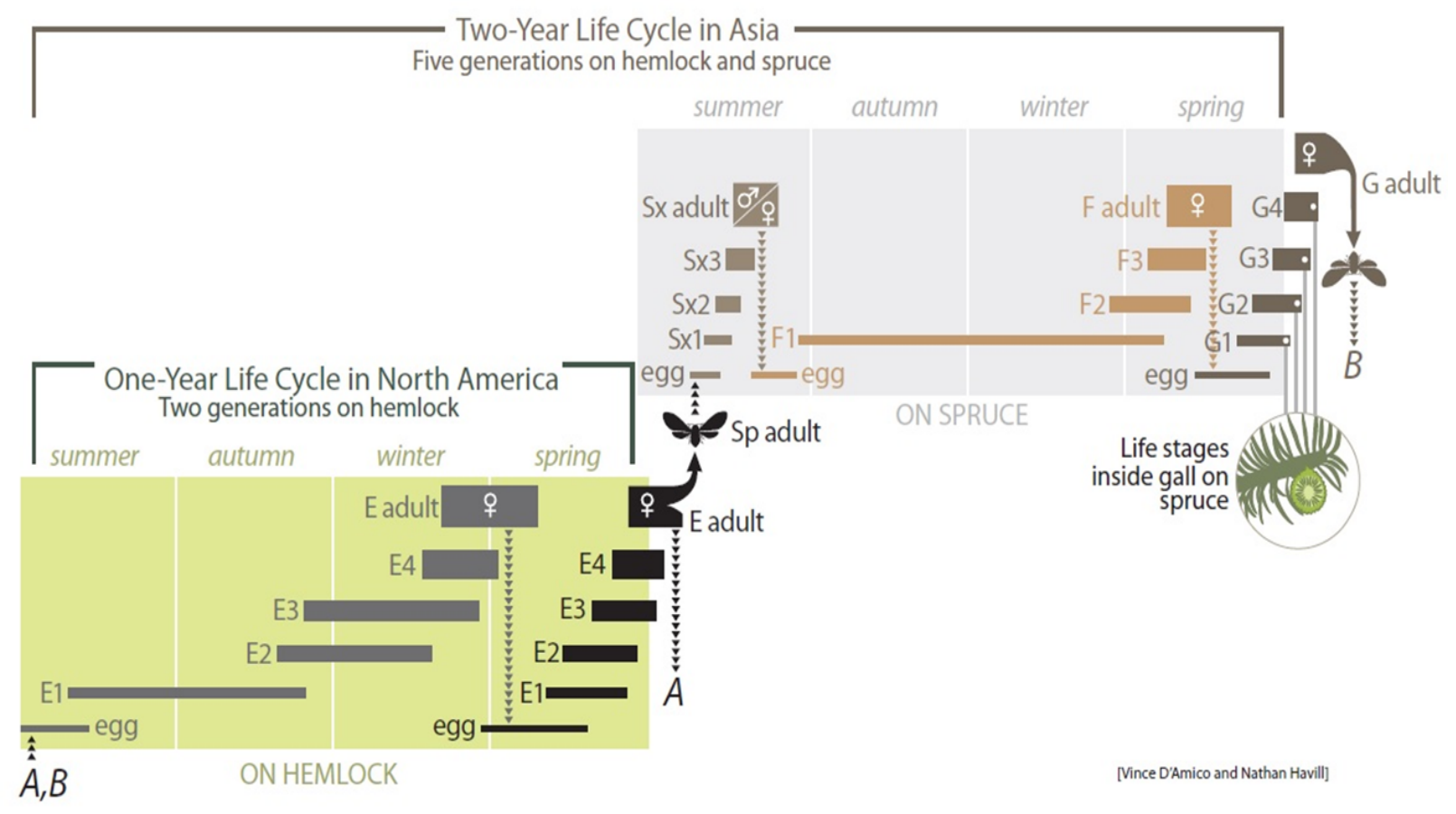

Figure 5: The presence of a suitable primary host in Asia means that the lifecylce is different there than that of North America (Nathan Havill, USDA Forest Service, Northern Research Station).

\section{Infestation \& Damage Dynamics}

Initially, HWA can be found on all ages of tree growth. However, the softer newest growth is more susceptible to infestation. It does not take many HWA to severely injure new shoots, reducing the production of future shoots. With fewer shoots in the second year of infestation, HWA mortality leaves populations on the older growth. As the third year progresses, the number of new shoots increases along with the HWA populations. With fewer shoots in year four, severe stunting of growth occours. This phenomenon, by which the population ebbs and flows in a bimodal pattern, is known as density dependant feedback (McClure 1991; McClure 1987). 


\section{Feeding}

Upon hatching, crawlers search for a suitable site to feed. Presumably, they use bristles on their antenna, mouth, and legs as sensory organs. The insect settles at the base of needles on tender new growth where the waxy coating is thinnest, nutrient content is highest, and lignin is less abundant. Once settled, they use their stylets to feed. The long, thin, straw-like mouthpart penetrates epidermal cells, travels far along the vascular bundle between cells, and ultimately reaches and then taps into the xylem parenchyma cells where carbohydrates are stored (Preisser et al. 2014; Young et al. 1995).

While this seemingly small mouthpart is often thought of as one mouth piece, it is technically a bundle. Four individual stylets come together forming two canals. One canal can inject saliva while the other can draw nutrients from the tree. Salvia serves two suspected purposes: to carry bacteria for nutritional purposes and to harden around the stylet-bundle. The hardened shell allows of the removal and reinsertion of the stylet bundle as the insect ages and molts. Between removal and reinsertion, HWA will shed its cutitle. This process allows for feeding throught the entirety of the its life. (Havill et al. 2014; McClure and Cheah 2002; Young et al. 1995).

\section{Damage Symptoms}

Feeding causes discoloration, desiccation, loss of needles, bud abortion, and branch dieback (McClure and Cheah 2002; Preisser et al. 2014). It appears there is no pattern to the distribution of HWA throughout tree canopies (Joseph et al. 2011). Often, effects can be visible after one year of infestation, while death can come in as little as three years. These figures are 
highly dependent on environmental factors, such as soil moisture (McClure 1987; Joseph et al. 2011). Reports exist of trees lingering in a feeble state after fifteen years of infestation. Mortality rates as high as $90 \%$ have been reported in some stands, such as the Shenandoah National Park (Townsend and Rieske-Kinney 2006).

\section{Damage Causes}

Research has suggested that the intense effect of $A$. tsugae upon eastern hemlock may not be solely caused by the consumption of parenchyma resources (Young et al. 1995). It is theorized "hypersensitive" reactions may be either a defensive response by which the tree kills nearby growth, thus limiting a food source or an induced response by which HWA increases local nutrient levels. In theory one, the killing of tissue causes false growth rings that interfere with water and solute transport, yet causes little harm to HWA and more harm to the tree. According to theory two, HWA may manipulate the plant through the secretion of enzymes. Amino acid concentration alterations have been found in HWA infested hemlocks. It is posed that this may be a similar process that occurs in galling insects (Preisser et al. 2014).

\section{Biological Controls}

Integrated pest management (IPM) is a way that technicians handle pests of all types with various tools to avoid indiscriminate use of chemicals in the environment (Hokkanen 2015). Biological controls are just one option and, while perhaps more useful in forest management, they have made their way into the tree care industry as evident with other pests. 
The first step in establishing such a control, is to identify predators in the native range of HWA. After identification, predators are studied in laboratories - where they are quarantined if outside their native range, reared, and finally released into the field (Cheah et al. 2004). Several predators have been identified and show promise, including three beetles from China (Scymnus sinuanodulus, S. camptodromus, and S. ningshanensis); a mite (Diapterobates humeralis); and two beetles, Sasajiscymnus tsugae - formerly known as Pseudoscymuts tsugae - and Laricobius nigrinus (Havill et al. 2014).

Many traits must be present to make a suitable predator, such as cold hardiness, life cycle synchronization between predator and prey, fecundity, and veraciousness. Therefore, some of these individuals have shown more promise than others in field trials. For example, the mite ( $D$. humeralis) was identified in Japan, brought to the U.S. and studied, then finally released only to find it does not reproduce prolifically enough (Onken and Reardon 2011). Others, such as $L$. nigrinus and S. tsugae, have shown promise, although not without shortcomings. Currently research has begun investigating similar species (L. rubidus and L. oakensis) within the genus to discover a more suitable predator (Havill et al. 2014, Cheah et al. 2004). See Figure 6.
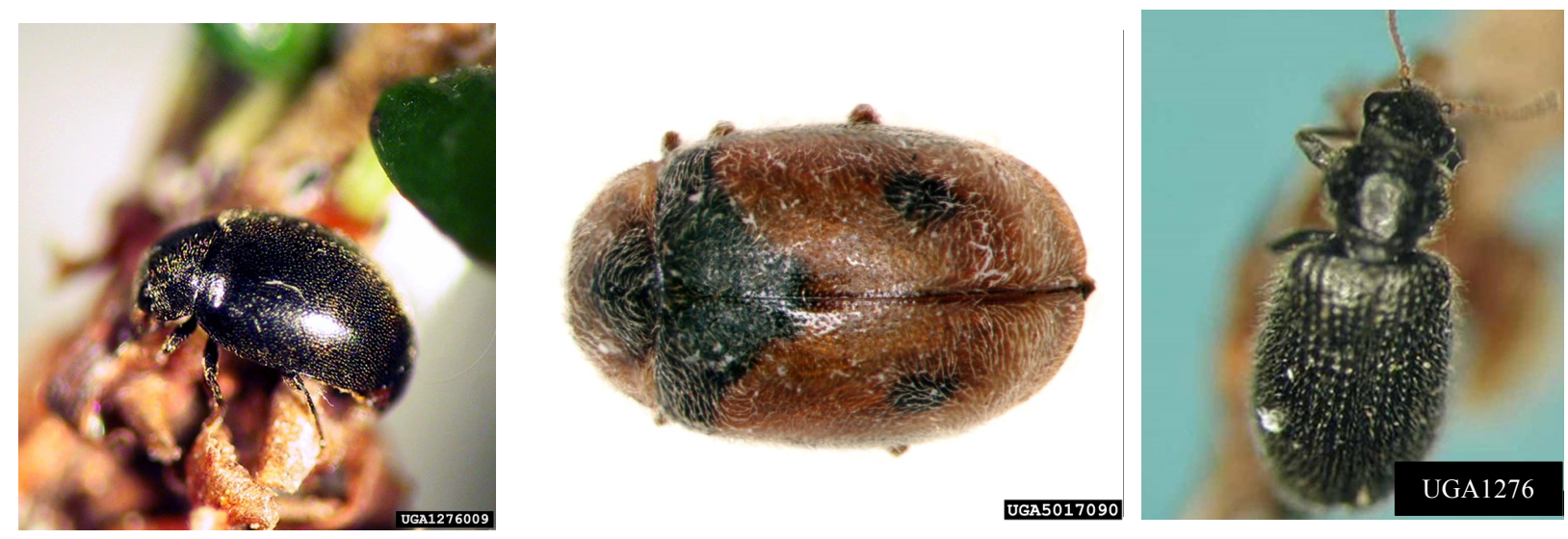

Figure 6: Potential biological control for HWA in North America. From left to right; Sasajiscymnus tsugae, Scymnus ningshanensis \& Laricobius nigrinus. All are shown in adult stage. These have not yet been proven to be dependable enough to combat HWA in a way that chemical options can. Photos coursey of bugwood.org Refence numbers can be found in lower right corner. 
Fungal pathogens are an area being explored as they too are environmentally friendly, although they are more expensive. Several are already used in the greenhouses of the horticulture industry. Pathogens such as Beauvaria bassiana, Metarhizium spp., Paecilomycetes fumosorosues, Purpureocillium, Trichoderma and Lecanicillium spp have all been successfully used there for several pests, including white flies and thrips. L. spp. are one of the more suitable fungi and are currently being sold and further explored. The pathogens of this genus attach to the exoskeleton, penetrate the cuticle wall, and then use hyphae to remove nutrients from the internal cavity. A commercial version of L. muscarium branded as Mycotal is distributed by Koppert B.V. Recent research shows that when released, this pathogen does not persist long enough to affect HWA (Wickert 2016).

\section{Imidacloprid}

\section{Alternate options and imidacloprid development}

Two insecticide types can be used for HWA treatment: horticultural oils and synthetic insecticides. Highly refined petroleum products, termed "horticultural oils", work quite well on many insects regardless of their feeding type (Sunoco 1994). This is because the chemical properties allow for respiration and membrane disruption of the target insect (Dilling et al. 2009, Johnson 1985). It also happens to be one of the safest pesticides to both mammals and the environment. Oils have been used as a pesticide for over 100 years, well before the DDT era (Johnson 1985).

Oils are mixed with water and sprayed onto to plant foliage. Depending on the time of year, they are mixed at one or two percent to avoid burning foliage in hot weather. In the case of 
HWA, application is through use of a hydraulic sprayer allowing arborists to reach canopy tops. It must be applied thoroughly around the tree and to the point of runoff (Rhea 1995). As there is no residual, timing is important. Ideally, applications are made to target adelgid at its most vulnerable life stages - the crawler or nymph stages - so that the treatment is most effective. Best management guidelines, provided by state extension services, often recommend three treatments a year (Lamb et al. 2011).

Besides oils, several insecticides belonging to the group known as neonictinoids can be used for treatment. Dinotefuran and acetamiprid are approved for bark applications. Dinotefuran works rapidly and even treats elongate hemlock scale, another serious pest of eastern hemlock (Cowles 2010). Suppression of HWA is reported to be from $79 \%$ to $87 \%$ one month after application (Joseph et al. 2011). Acetimprid trunk injections have been successfully used in HWA treatments. (Joseph et al. 2011, Persad unpublished). Other unpublished research into imidacloprid's use as a bark spray reports that of several neonicotinoids tested on $\sim 3 \mathrm{~m}$ tall hemlocks, acetamiprid is one of the most readily absorbed and translocated (Cowles unpublished).

Of the four insecticide classes available in the 1980 s - carbamates, pyrethroids, organophosphates, and pheno-pyrazoles - many pests had developed resistance to the first three (Simon-Delso et al. 2015). During this period, the compound imidacloprid was discovered by Professor Shinzo Kagubu while working for Shell Development Company. Soon after it was introduced onto the market in 1991 (Tomizawa and Casida 2010).

Its discovery and introduction ushered in the era of a new class of insecticides: neonicotinoids, synthetic compounds derived from the naturally occuring insecticide nicotine. 
Since then, seven have been introduced: imidacloprid, thiacloprid, clothianidin, thiamethoxam, acetamiprid, nitenpyram, and dinotefuran (Jeschke 2011). By 2008, this new fifth class now constitues a quarter of the insecticide market (Casida and Durkin 2013). Their popularity has grown because of their insecticidal control, low risk to non-target organisms, and systemic capabilities (Tomizawa and Casida 2010). Neonicitinoids happen to be the most effective insecticide for the control of piercing/sucking insects such as aphids, leafhoppers, and thrips.

\section{Characteristics}

Merit ${ }^{\circledR}$, the first branded formulation of imidacloprid came off patent in 2006. Since then, many other generic formulations have been produced. A few trade names include Xytect 75 WSP ${ }^{\circledR}$, Touchstone ${ }^{\circledR}$, and Advantage ${ }^{\circledR}$. According to chemical nomenclature conventions, imidacloprid is known as 1-[(6-chloro-3-pyridinyl)methyl]- $N$-nitro-2-imidazolidinimine (Tomizawa and Casida 2003). It is considered a broad-specturm pesticide, meaning it is effective against a wide variety of insects. As a neonicitinoid, it works as a contact spray and systemic application and therefore is a popular choice when handling Adelgs tsugae. The ability to move through the xylem is result of the high water solubility, low vapor pressure, water partition coefficient, and dissociation coefficients. Due to the mode of action, imidacloprid possesses a low to moderate mammalian toxicity and a class III to II toxicity rating (Lamb et al. 2011). The nature of its chemical composition makes it non-volatile, gives it a low potential for volatizing from water as well as a low soil absorptioncoefficient, known as "Koc" ( Fossen 2006). This, in part, is why it has become one of the most common pesticides globally. Characteristic details can be found in Figure 8. 


\section{Mode of Action \& Lethal Concentrations}

By binding to the post-synpatic nicotinergic acetylcholine receptors of neurons, imidacloprid interferes with normal nerve impulse transmission. Normally acetylcholine, the major excitatory neurotransmitter, is bound to and then degraded by the inactivating enzyme acetylcholine esterase. Mimicking acetylcholine, imidacloprid heightens and then blocks the firing of the postsynaptic receptors. However, imidacloprid is not removed by acetylcholine esterase. This causes uncontrolled muscle reflexes, paralysis, and death (Tomizawa and Casida 2003).

Leathal concentrations, termed " $\mathrm{LC}_{50}$ ", is the measure of the inseciticidal concentration required to kill $50 \%$ of a sample population of a specific organism. Imidacloprid literature has attempted to establish links between the lethal concentration, HWA mortality, and effectiveness.

Laboratory experiements testing the link between concentration and HWA mortality do so by first removing an infested distal branch and dipping the cut end in a imidacloprid and water solution. HWA mortality is measured at a set number of days after initiation. Laboratory tests have calculated a $\mathrm{LC}_{50}$ of $300 \mathrm{ppb}$ twenty days post treatment and $\mathrm{LC}_{50}$ of $242 \mathrm{ppb}$ thirty days post treatment. Meanwhile, field tests have found the $\mathrm{LC}_{50}$ to be roughly $120 \mathrm{ppb}$ (Cowles and Lagalante 2009, Eisenback et al. 2010).

Literature has also attempted to link concentration and adelgid to efficacy through a variety of measurements such as the appearance of tree health, new shoot length, or percentage of shoots infested (PSI). Jeffrey Fidgen, in developing a simple method of quantifying HWA populations based on PSI, established two thressholds: one based on aesthetics (10\%) and another on damage (30\%) (Fidgen et al. 2006). Research linking percentage of shoots infested to insecticide 
concentrations found that a $0 \%$ PSI was associated with $211 \mathrm{ppb}$ in branch tissue while a PSI $>1 \%$ was $41 \mathrm{ppb}$. Trees with $>30 \%$ PSI contained $>27 \mathrm{ppb}$ in their foliage (Eisenback et al. 2014). This means there is a range of efficacy associated with levels of concentrations.

\section{Imidacloprid Metabolites}

The imidacloprid molecule is made of three important chemical groups:

chloropyridinylmethl, imidazolidine, and nitroimine (Figure 7). When in solution, whether it be within the xylem or the soil, imidacloprid may metabolize, meaning the chemical groups comprising the parent compound may separate and recombine making new compounds, known as metabolites. This seperation and recombination takes place as imidacloprid hydrolyzes, oxidizes, or isomerizes when in solution. Metabolites may be more or less lethal than the parent compound. Imidacloprid-olefin, or "olefin" for short, is just one such metabolite. With a 15 day

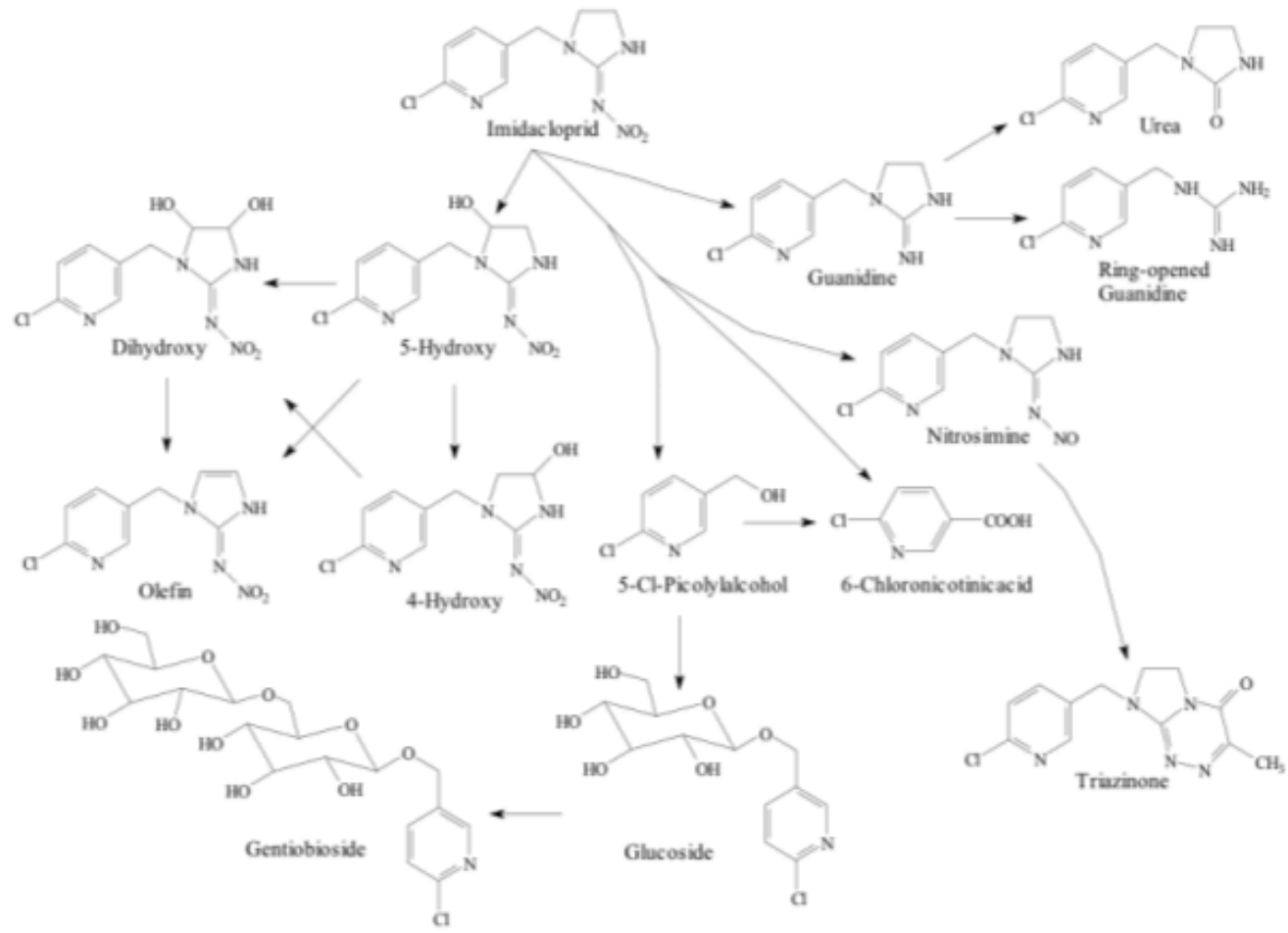

Figure 7: The parent compound and its metabolites are illustrated along with pathways in which they are formed (Placke \& Gustin 1993). The reduction and recombination of imidacloprid into different compounds occours as imidacloprid interacts with the environment where it may hydrolyze, oxidize, or isomerizes. 
$\mathrm{LC}_{50}$ of only $6 \mathrm{ppb}$, it has toxicity to HWA 10-16 times than that of the parent compound, imidacloprid. Olefin is believed to persist within the tree and provide it with a long periods of protection against adelgid (Benton et al. 2015). Metabolic pathways are illustrated in Figure 7.

\section{Dosage}

Currently label instructions direct users to base application rates off of a tree's diameter at breast height. This linear relationship has been found to provide small trees with excess product and an inadequate amount in larger trees (Benton et al. 2016). Such a phenomenon is undesirable, as a per acre per year limit is enforced by the EPA/DEC, constraining how many trees can be treated at a given area and time.

Several projects have been aimed at correcting this. So far research has determined an exponential relationship between tree diameter and water usage. Additionally, it has linked water movement volume through xylem to imidacloprid concentrations. Tests of water use dosages proved to be more efficient than the current diameter method (Ford et al. 2010). Future research linking water usage to crown volume could make use of the findings by producing technicians friendly dosage tables for inclusion in the manufacturer's instructions (Turcotte et al. 2015).

\section{Spatial Distribution}

The chemical properties discussed previously are what enable easy translaminar and xylem movement into shoots and leaves. Conversely, phloem movement to roots, fruits, and storage organs is poor (Elbert et al. 2008, Sur and Stork 2003). The older leaf portions can be 
expected to house the highest residues (Sur and Stork 2003). Movement of imidacloprid throughout a single branch was studied by comparing the concentration levels between xylem fluid in the twig and needles. Of the samples tested, significant differences were found; $27 \%$ had detectable levels of imidacloprid in both xylem fluid and needle tissue, $14 \%$ had levels on in the xylem fluid and not in the leaf tissue, $23 \%$ were vice versa, and $36 \%$ had no detectable levels in either. This implies insecticide movement is intermittent (Turcotte et al. 2017).

Despite the many tests conducted over the years, researchers are still trying to grasp precisely why and where imidacloprid moves within the canopy. Studies have repeatedly examined this by dividing the crown of treated hemlocks into three strata: bottom, middle, and top. Some studies show mean concentration is highest in the lowest strata while others have determined it is highest in the middle and top strata (Coots et al. 2013, Dilling et al. 2009, Turcotte et al. 2017, E. Benton et al. 2016).

\section{Temporal Distribution \& Longevity}

Imidacloprid can be detected within three months of application, peaks between nine to fifteen months, and declines from there. Meanwhile olefin peaks around thirty-six months post treatment. Studies looking into the four to seven year window post treatment have still detected imidacloprid concentrations below the HWA $\mathrm{LC}_{50}$. While this may be insufficient for adelgid mortality, it may contribute to adelgid suppression (Benton et al. 2015, Coots et al. 2013). 


\section{Environmental Fate}

In addition to being highly water soluble, imidaclorpid poorly adheres to soil particles and is highly toxic to acquatic organisms. This can be of concern as eastern hemlock is naturally found in riparian areas, where the potential leaching of imidacloprid out of the soil and into surface water is possible. A similar concern exists in urban area where movement into groundwater is possible. (Fossen 2006 ).

Research shows imidicloprid's ability to adhere to soil particles rises with the amount of soil organic matter (Liu et al. 2006). The Connecticut Agriculture Station has addressed these concerns more specifically related to soil drenches for hemlocks. Tests found that imidacloprid and dinotefuran do not travel more than a few inches from where they are placed provided $3 \%$ organic matter is present (Cowles 2009).

Extensive research examining ground water contamination in New York State's Long Island region may corroborate Cowles' findings. In a region where sandy soils are dominant, the human population is dense, and the water tables are shallow, 46,316 applications of imidacloprid were recorded in two out of its four counties; Nassau and Suffolk. The New York Department of Environmental Conservation (NYDEC) has taken 2,000 samples from 11 upper water table monitoring wells across Suffolk county from 2001 - 2010 to find the majority of wells contained less than $1.0 \mathrm{~g} / \mathrm{L}$ of imidacloprid. This is well below the NYDEC's maximum amount of $50 \mathrm{~g} / \mathrm{L}$, which is a standard eight times smaller than that of the Federal EPA standards (399 g/L) (Schatz 2017, NYDEC 2015). Provided it is applied to the soil in the correct conditions, when the soil is not dry or too saturated, imidacloprid can bind well to the soil. While Schatz does not provide 
speculate why groundwater contamination is low when imidacloprid application is so prevelant, I suspect it is due to the chemical properties and adhereance to better management practices.

In population dense urban areas, lingering of the product in the air would be another concern. A low vapor pressure and low Henry's law constant (Figure 8), mean it is unlikely to be present in the air in detectable amounts (Fossen 2006). While imidacloprid can be found in the soil and water, it does not persist long as imidacloprid is prone to photodegredation (EPA 2004).

\begin{tabular}{|ll|}
\hline Molecular weight & 255.7 \\
Water solubility & $514 \mathrm{mg} / \mathrm{L}\left(20^{\circ} \mathrm{C}\right.$ at $\left.\mathrm{pH} 7\right)$ \\
Vapor pressure & $1.00 \times 10^{-7} \mathrm{mmHg}\left(20^{\circ} \mathrm{C}\right)$ \\
Hydrolysis half-life & $>30$ days $\left(25^{\circ} \mathrm{C}\right.$ at pH 7$)$ \\
Aqueous photolysis half-life & $<1$ hour $\left(24^{\circ} \mathrm{C}\right.$ at $\left.\mathrm{pH} 7\right)$ \\
Anaerobic half-life & 27.1 days \\
Aerobic half-life & 997 days \\
Soil photolysis half-life & 38.9 days \\
Field dissipation half-life & $26.5-229$ days \\
Henry's constant & $6.5 \times 10^{-11}$ atm m${ }^{3} / \mathrm{mole}\left(20^{\circ} \mathrm{C}\right)$ \\
Octanol-water coefficient $\left(\mathrm{K}_{\mathrm{ow}}\right)$ & 3.7 \\
Soil adsorption coefficient: & \\
$\mathrm{K}_{\mathrm{d}}$ & $0.956-4.18$ \\
$\mathrm{~K}_{\mathrm{oc}}$ & $132-310$ \\
\hline
\end{tabular}

Figure 8: Specifications of characteristics related to environmental fate from Fossen, 2006. These chemical properties define imidacloprid's characteristics. At $514 \mathrm{mg} / \mathrm{L}$, imidacloprid is moderately water soluable. It is by this ability imidacloprid can penetrate bark. With a low vapor pressure, it will not vaporize easily, meaning it won't linger in the air. With an aqueous photolysis halflife, imidacloprid will break down from the presence of light when in water. Its Koc does not allow it to bind to soil particles easily.

\section{Non-target Organisms}

Concerns of negative externalities include the insects of the forest ecosystem.

Fourhundred eighty-four arthropods have been associated with Tsuga canadensis (Turcotte 2015). Research exploring the effects of imidacloprid applications on arthropods is contradictory. Of the 484 arthropods investigated by Turcotte (2015), no difference in mean population levels were found when compared to the untreated control. Dilling (2009) conducted 
similar research where he specifically examined the effects of various imidacloprid application methods and concentration levels on nontarget canopy insects associated with eastern hemlock, in particular phyotophygus and transient insect communities. This accomplished by measuring specimen abundance, species richness, and guild abundance. Findings included: thirty-three nontarget canopy species were directly affected by treatments, application timing had no impact, and that higher concentrations of imidacloprid had effects on several of the metrics mentioned above. Several individual species are more sensitive to soil injections and drenches since they pupate in soil (Dilling et al. 2009).

Throughout the 1990s, arborists of the mid-Atlantic region observed high levels of mite infestations on hemlocks following imidacloprid application. Two studies investigating this issue concluding elevated mite populations are not present in every case of imidacloprid treated specimens (Raupp et al. 2004). The exact reason for this phenomenon is still unknown, however three common hypotheses include: sub - lethal doses stimulates mite reproduction, imidacloprid may eliminate or suppress mite predators, and imidacloprid alters hemlock physiology in a way beneficial to mites (Raupp et al. 2004). Treating for HWA and secondary outbreaks of mites, if necessary, is common practice amongst arborists.

Since 2007, Honey bees (Apis spp.) in the U.S. have been hit heavily by colony collapse disorder- sometimes refered to as CCD. Systemic neonicotinoids on the whole are a suspected cause. In the U.S. local, state, and federal decision makers are taking precautions to protect pollinators from neonicotinoids (Cowles 2010). It should be noted that the cause of CCD is still unknown (USDA 2012). On one hand, a review of the disorder around the world suggests several other explanations. On the other hand, imidacloprid has attributes that does not leave it 
off the hook. Either way, hemlocks, like all pines, are wind pollinated meaning no effects to pollinators are anticipated.

\begin{tabular}{|ll|}
\hline Daphnia magna $\mathrm{LC}_{50}(48 \mathrm{~h})$ & $85 \mathrm{mg} / \mathrm{L}$ \\
Mysid shrimp $\mathrm{LC}_{50}(96 \mathrm{~h})$ & $37 \mathrm{mg} / \mathrm{L}$ \\
Rainbow trout $\mathrm{LC}_{50}(96 \mathrm{~h})$ & $211 \mathrm{mg} / \mathrm{L}$ \\
Bobwhite quail $L D_{50}$ & $152 \mathrm{mg} / \mathrm{kg}$ \\
Mallard duck $\mathrm{LD}_{50}$ & $283 \mathrm{mg} / \mathrm{kg}$ \\
Rat acute oral $L D_{50}$ & $450 \mathrm{mg} / \mathrm{kg}$ \\
Honeybee $\mathrm{LD}_{50}(48 \mathrm{~h})$ & $0.008 \mathrm{\mu g} / \mathrm{bee}$ \\
\hline
\end{tabular}

Figure 9: Toxicity ratings for various organisms (Fossen, 2006). Lethal concentrations or Lethal doses is the required amount of active ingredient needed to kill $50 \%$ of a test population after a specified amount of time.

\section{Application Methods}

A variety of options exist, each having associated advantages and disadvantages. An arborist assesses each application method by their ease of application and off target potential. Treatment of hemlocks in the urban or residential sector often takes place in close proximity to people, pets, and structures, bringing the concept of off-target potential to the forefront of technician's minds.

Imidacloprid foliar sprays have found to be effective against adelgid populations (Cowles and Cheah 2002). When treating small trees or shrubs such a spray can be applied through use of a backpack sprayer while large trees require the use of larger hydraulic sprayers. In either case, just enough should be used to evenly coat the crown. When applied in this manner imidacloprid has rapid activity and a short residual (Silcox 2002). Tall trees or obstacles may preclude specimens from this method as hydraulic sprayers may not reach the treetops and may produce drift, increasing the risk of off-target damage (Figure 10). 
Three types of soil treatments exist: soil drenchs, soil injections, and tablets. Soil drenches (Figure 11A) are conducted by making a shallow trench around the base of the trunk and then pouring the mixture inside where the fluid is retained adjacent to the trunk. By contrast soil injections require equipment that allow the technicians to place the mixture below the surface and close to the roots, either around the dripline, in a grid within the dripline, or adjacent to the trunk (Rainbow Treecare Scientific 2012). Dosage is determined by DBH in both cases. Specialized soil injectors can be purchased (Figure 11B \& C), or a more generic injector may be assembled rather easily. This can be done by simply plumbing a commonly available "fertilizing/root feeding gun" onto a spray hose of any portable container such as a backpack or a bottle sprayer as shown in Figure 11D \& D. Tablets can be placed $5-10 \mathrm{~cm}$ below the soil, roughly $22 \mathrm{~cm}$ from the trunk or at the dripline when necessary. This treatment method places the active ingredient as well as fertilizer in the root zone for uptake (Bayer Environmental Science 2017).

Soil application methods have been proven to reduce HWA populations one to two years post treatment by $80 \%$ and $98 \%$ respectively (Cowles and Lagalante 2009). Compared to tablets research shows soil injections work slightly faster than tablets. Injections have produced lethal concentrations (>120 ppb) to HWA in as little as three months. Tablets took 12 months to cross this threshold (Cowles and Lagalante 2009, Eisenback et al. 2014). 


\section{Application Timing}

Several projects investigating whether spring applications or fall applications yields a higher imidacloprid concentration have produced conflicting results (Turcotte et al. 2017, Coots et al. 2013, Eisenback et al. 2014, Cowles and Lagalante 2009). Two of these studies report higher concentrations associated with spring applications, while the others found no difference among seasons. While this has not been reconciled, Carla Coots poses this may be due to regional differences, as the hemlocks of the Southern Appalachians transpire year round, unlike those of the Northeast (Coots et al. 2013).
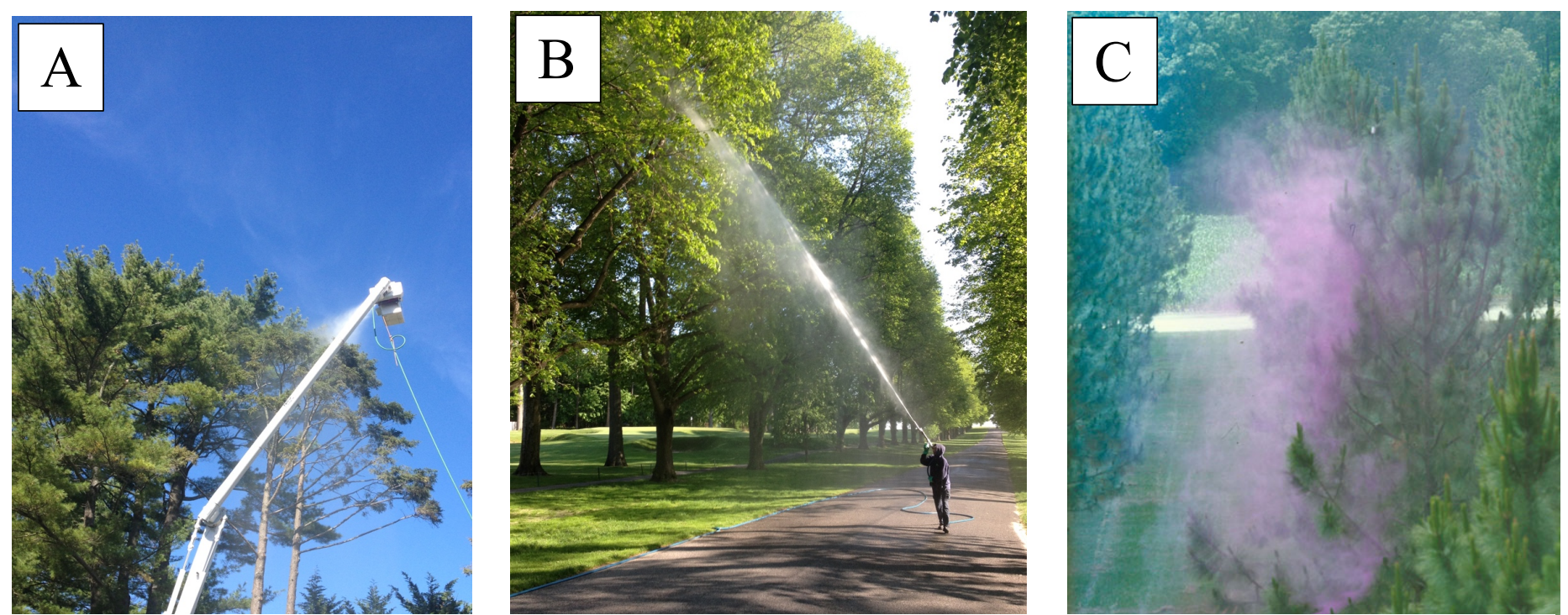

Figue 10: The limitations of spray equipment. Photo A shows the author using a bucket truck to treat $\sim 21 \mathrm{~m}$ hemlocks with horticultral oil. Photo B shows the author spaying lindens $\sim 16 \mathrm{~m}$ tall where drift is clearly depicted. Photo C too illustrates how much sprays drift through the use of a purple dye. This drift is highly undesireable for technicians in dense urban areas such as in photo A which was taken at a large home with construction taking place at time of application. Coordination with the homeowner and construction crew was required to clear the area of people. Other applications types such as soil and bark applications could avoid this. Photo C is courtsey of bugwood.org 

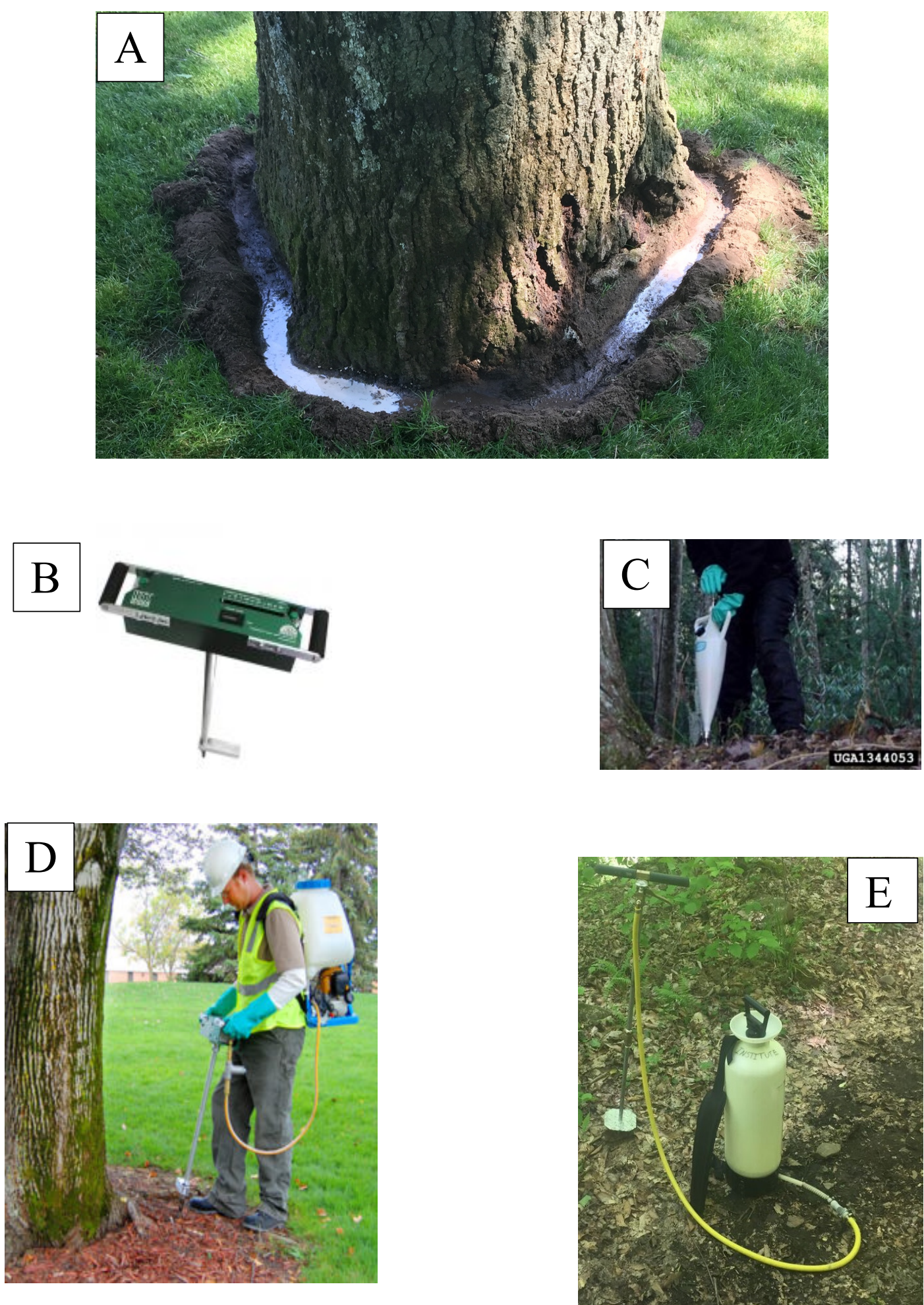

Figure 11: A: soil drench. B: self-calibrating injector. C: Kioritz Soil Injector.. D: backpack \& soil injector E: bottle sprayer \& injector. The equipment shown runs a wide range of prices and arborists may possesses some of the pieces. The metal injectors pictured in $D \&$ Ecan be easily assembled with parts from a hardware store and are also used for sub-surface injections of fertilizer. Pictures $B \& D$ courtesy of Rainbow Treecare Scientific, C of bugwood.org. 
There are a handful of trunk injection techniques including the Wedgel Direct Injection System, Mauget microcapsules, and the family of systems by Arborjet (Figure 12). While all these systems operate in a slightly different fashion, they function on the same basic principles; product is fed directly into the xylem by taping the tissue with a drill, plug, or needle. With the xylem tissue tapped, pressure is supplied in some manner.
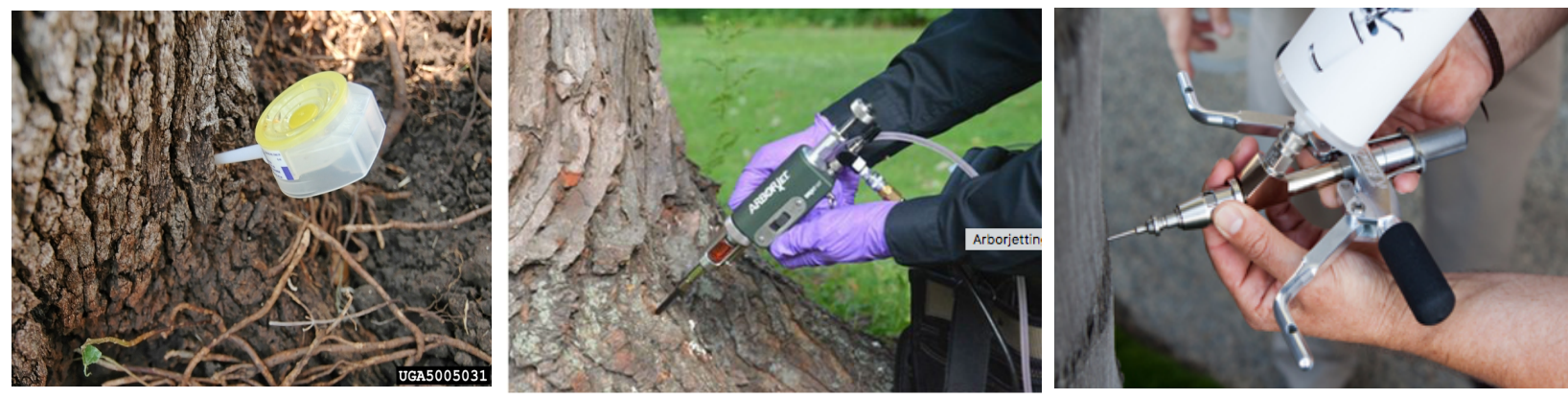

Figure 12: From left to left to right; Mauget Micro Injection Capsules, Arborjet "Viper System", \& the Wedgel Direct Injection method. Phtos Coursey of www. forestryimagery.org, Arborjet, and Arborsystems ${ }^{T M}$ respectively. The options are not limited to these three systems and like all professional equipment, these run a range of prices and are all slightly different in how they operate.

Research has produced varying results in regard to these injections. Work done by the Connecticut Agricultural station shows that a variety of these trunk methods showed no reduction in adelgid populations compared to untreated controls. Twig concentration showed that all of the tested trunk injection methods - Arborjet, Mauget, and Wedgel- Mauget was the only one that provided high levels of imidacloprid (240 ppb). Even in the case of Mauget, these high levels happened to only be peaks that diminished in a matter of months. And in all cases of trunk injections, no adelgid population control was achieved The authors pose these results were due to uneven distribution throughout the canopy. Compared to the soil injections methods tested, the agricultural station found soil injections provided higher concentrations and a more uniformed distribution throughout the canopy (Cowles and Lagalante 2009). 
Similar research strictly comparing Mauget trunk injections to soil injections found that there was no difference in the adelgid populations or the number of shoots infested by those populations in the soil and trunk injections. The author states the injection method was on par with soil injections as it not only reduced the adelgid population but the number of shoots infested by the population as well. Differences were found in how the imidacloprid concentrations changed in the two treatments. Concentrations in the trunk injections appeared more quickly, reached a higher peak, and dissipated more quickly than the soil injections. The suggests the cause of the disparity between the Connecticut study and his own is due to differences in how trunk injections were performed (Eisenback et al. 2014).

\section{Bark Applications}

Bark applications have been researched since at least the 1960s (Norris 1967, Pielou 1961). Other chemicals have been applied in this manner on what appears to be a handful of hosts/pests. This method stands to provide several benefits over other application methods. Early research shows depending on the product sprayed, bark applications could require as little as $1 / 10-1 / 5^{\text {th }}$ the amount of active ingredient required in soil applications to attain the same levels of concentrations. Literatue also proposes that they are not as dependant on water uptake compared to the soil applications (Norris 1967). It only follows that water could be carried more conveniently. Less product applied in a precise manner would eliminate the possibility of chemical drift while reducing environmental exposure when compared to foliar and soil applications. Frift elimination means reducing the concen of chemicals moving onto adjuacent properties where children, pets, or valuable property may be screened by obstacles. This is 
important to technicians as there are legal ramifications as state and federal agencies have laws to discourage this. More efficient use of the product means less sits in the soil where it may leach into waterways. This could be beneficial in forestes where eastern hemlock is often found in riparian settings. It stands that bark application may be easier to haul, cheaper to apply, friendlier to the environment, while eliminating tree wounds. The method is pictured in Figure 13.

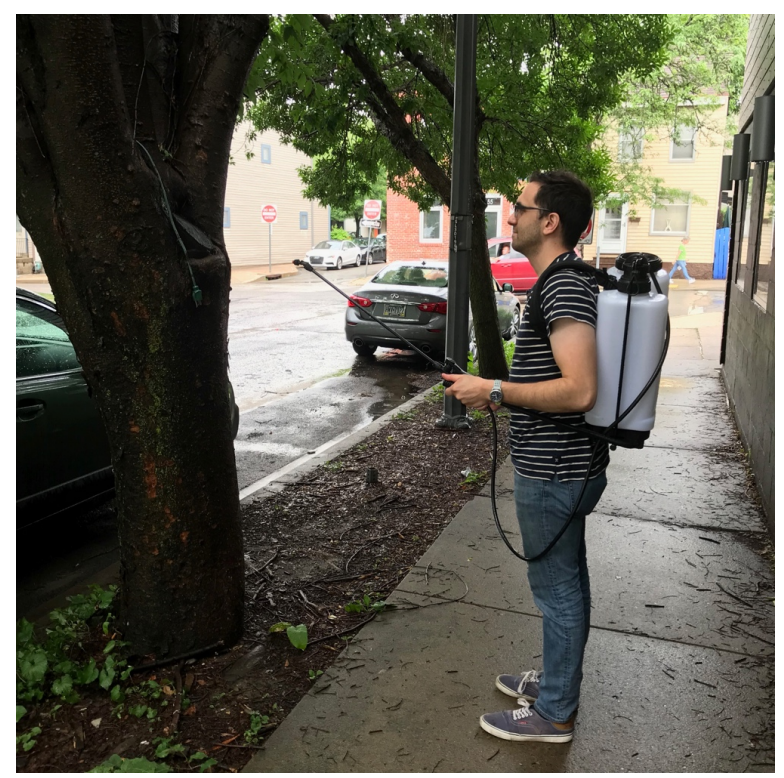

Figure 13: Bark applications are made using a backpack sprayer. Pressure is created by pumping the handle in the technitian's left hand. When the handle on the wand is squeezed, the insecticide is released. It is applied from the technitian's breast height down to the ground and is done to all sides of the trunk. The photo is to showcase the equipment and is not of an actual treatment, hence the lack of protective equipment.

\section{Adjuvants \& Bark Penetration}

Pentra-Bark ${ }^{\circledR}$ is a surfactant and is used in combination with water soluble pesticides of all sorts. Marketing material states that when incorporated into the water/pesticide mixture, Pentra-Bark ${ }^{\circledR}$ proposedly opens bark lenticels to allow for pesticide movement directly into xylem tissue (Pentra-Bark 2017). When used with noenicitinoids, there is little evidence it provides the desired effect. Two studies examining basal bark sprays of noenicitinoids found that 
Pentra-Bark ${ }^{\circledR}$ did not have any affect on mortality (McCullough et al. 2011; Cowles 2010).

Conversely, it has been found to make a difference on phosphite treatments of coast live oak for sudden oak death (Garbelotto et al. 2007).

While adjuvants are supposed to aid in penetration, penetration of the bark can occour without it through a process known as "active entry". This phenomenon is the method by which water soluable pesticides are absorbed through cell walls of the periderm, into the cortical parenchyma and finally, into the phloem nd xylem by cell to cell passage. This does not mean systemics can pass bark of all species as thick bark of mature trees may be impermeable. In the early years of experimentation, results show the larger the area to which a product is applied, the greater the degree of insect morality is observed (Norris 1967).

\section{Detection in Tissue}

The first detection method is through the use of an enxyme-linked immunosorbent assay, abbreviated "ELISA". This method used for testing xylem fluid is inexpensive but can result in falsely elevated concentrations of imidacloprid. This is due to cross-reactions between several of the metabolites associated with imidacloprid (Turcotte et al. 2017; Lagalante 2007).

Gas chromatography with positive chemical ionization mass spectrometry ,also known as GC-PCI/MS, confirmed the cross reactions occouring with ELISA. This method was developed to overcome these issues and is used for detection in both xylem fluid (Lagalante and Greenbacker 2007). 
Flow injection analysis with nitric oxide chemiluminescence detection (FIA NOCL) may be used on xylem fluid and needles. Detection is through the degredation of imidacloprid to its metabolites. Cross reaction of metabolites is also an issue in this method (Lagalante 2007; Lagalante and Greenbacker 2007).

Liquid chromatrophy tandem mass spectometry, LC/MS/MS, can also be used for testing xylem fluid and needles. This technique does not suffer from inflated concentrations as other methods due and is able to detect metabolites in addition to the parent compound (Lagalante 2007, Turcotte et al. 2017). 


\section{Chapter 3: Comparison of Biological \& Financial Efficacy of Bark Treatments}

\section{Introduction}

Eastern hemlock (Tsugae canadensis Annand) inhabits much of North America's Eastern Seaboard. Prefering slopes and decent drainage, it can be found from Nova Scotia to Minnesota, then south along the Appalachian Mountains to Alabama and Georgia (Dirr 1998). Meanwhile, Carolina hemlock can be found in isolated areas throughout the Southeast, making it limited in number (Burns and Barbara 1990). The more populus eastern hemlock, the focus of this paper, has been used as a specimen, screen, or group planting throughout urban areas. Its popularity has brought on the production of several cultivars for dwarf, compact, and weeping qualities (Dirr 1998).

Much of eastern hemlock's native range has been effected since the 1950 disovery of hemlock woolly adelgid, Adelges tsugae L. Carrière (Hempitera: Adelgidae), in the United States. DNA evidence suggests hemlock woolly adelgid, or HWA, arrived prior to this date from Southern Japan and did not mirgrate from the North American West Coast where this pest is also native (McFlure1987; Havill et al. 2006).

HWA can be found on all ages of tree growth following initial infestation, although soft new growth is the most susceptible. It does not take many to injure new shoots, reducing the production of future shoots. With fewer shoots in the second year of infestation, mortality leaves populations on older growth. As the third year progresses the number of new shoots increases, as does the HWA population, bringing about fewer shoots in year four, where stunting of growth 
occours. This ebb and flow of the population is known as density dependant feedback (McClure 1991; M. McClure 1987).

Over the decades, arborists have handled this pest using several insecticides and application methods. The interaction of an insecticide's chemical properties and federally approved application method gives each product unique characteristics. Such characteristics may make one product more favorable than another depending upon the environment where applications are being made. With a handful of products and methods for HWA, treatment means expanding either would benefit arborists and land managers. Highly refined petroleum products, termed "horticultural oils", are one product that work quite well on many types of insects regardless of their feeding type (Suonoco 1994). This is due to how it affects insect respiration and their membranes (Dilling et al. 2009, Johnson 1985). It happens to be one of the safest pesticides to mamals and the environment and has been used for many pests over a century (Johnson 1985).

Of the four insecticide classes available in the 1980s - carbamates, pyrethroids, organophosphates, and pheno-pyrazoles - many pests had developed resistance to the first three (Simon-Delso et al. 2015). During this period, the compound imidacloprid was discovered and introduced to the market in 1991 (Tomizawa and Casida 2010). This ushered in the era of neonicotinoids, a class of synthetic compounds derived from the naturally occuring insecticide nicotine. Since then, seven more neonictinoids have been introduced (Jeschke 2011). By 2008, this new fifth class constituted for a quarter of the insecticide market (Casida and Durkin 2013).

As a neonicitinoid, imidacloprid works as a contact spray and systemic application and therefore is a popular choice when handling HWA. The ability to move through the xylem is 
result of the high water solubility, low vapor pressure, water partition coefficient, and dissociation coefficients. Due to the mode of action, imidacloprid possesses a low to moderate mammalian toxicity and a class III to II toxicity rating (Lamb et al. 2011). Its lack of volatility gives it a low potential for volatizing from water and a low soil absorptioncoefficient, known as "Koc" (Fossen 2006). This in part is why it has become one of the most common pesticides globally.

Currently soil drenches, soil injections, tablets, and foliar sprays are the approved methods of applying imidcloprid for HWA control. Soil injections and soil drenches both require some equipment, such as spray rigs or specialized injectors while tablets don't require any. Foliar applications require specialized equipment. The spray rigs and heavy hoses that are used limit how high a treatment can reach in addition to creating chemical drift. This fine mist lands off the intended target and perhaps onto adjacent properties. This uneccsarily exposes the environment to chemicals and the applicators to potential liability.

Professional arborists might prefer a less cumbersome and quicker method for treating HWA. Bark applications certainly meet these crtiera and have been investigated at least as far back as the 1960s. Other pesticides have been appoved by the EPA for use in this manner including Agri-fos ${ }^{\circledR}$ for sudden oak death (Phytophthora ramorum), Safari ${ }^{\circledR}$ for elongate hemlock scale (Fiorinia externa), and Baseline ${ }^{\circledR}$ for bark beetles (Dendroctonus spp.). This method stands to provide several benefits over other application methods. Early research shows depending on the product sprayed, bark applications could require as little as $1 / 10-1 / 5^{\text {th }}$ the amount of active ingredient required in soil applications to attain the same levels of concentrations (Norris 1967, Pielou 1961). 
Basal bark applications stand to reduce translocation time, labor costs, material costs, and minimize the exposure to the environment. By comparing treatments of imidacloprid as a bark spray to soil applicationthis project will determine: 1.) if bark applications produce any imidacloprid or olefin concentrations 2.) whether labeled rates influence detectable levels of either compound 3.) the neccessity of an adjuvant 4.) if bark applications reduce A. tsugae populations 5.) the feasibility of such an application. These comparative results will indicate wether this method can serve as another tool in the integrated pest management toolbox.

\section{Methodology}

Research was conducted at Fallingwater, a Western Pennsylvania Conservancy property located in Mill Run, Pennsylvania. All trees lined the Bear Run Trail. The surrounding area was comprised primarily of silt loams, slopes between $35 \%$ and $70 \%$, and is extremely stony (NRCS 2017). Prior to field treatment, 56 trees meeting basic criteria were identified, flagged, and numbered. Criteria included species, height, and spacing. Trees selected were eastern hemlocks, between $1.5 \mathrm{~m}$ and $11.2 \mathrm{~m}$ tall, and no closer than $9 \mathrm{~m}$. The height requirement was to ensure all canopies could be accessed while the minimum distance between trees was to reduce the possibility of movement of product through the soil from tree to tree. Live Crown Ratio (LCR) and diameter at breast height (DBH) was measured at this time to gauge whether these cofactors influenced insecticide concentrations.

Once identified, trees were randomly assigned to recieve one of seven treatments; six with imidaclprid and a seventh untreated control (Table 1). These imidacloprid treatments included a soil injection at the low labeled rate, soil injection at the high labeled rate, bark 
application at the low labeled rate, bark application at the high labeled rate, bark application at the low labeled rate plus an adjuvant, and a bark applicatin at the high labed rate plus an adjuvant. The adjuvant rate was held constant in the middle of the labeled range $(5.6 \mathrm{~mL} / 4.5 \mathrm{~L})$. Eight trees were treated in each of the seven ways listed (totaling fourty-eight treated treas and eight untreated trees).

Table 1: Treatment types \& dosages. *Adjuvant was mixed at $5.6 \mathrm{~mL}$ of adjuvant for $4.5 \mathrm{~L}$ of mixture in both groups where adjuvant was used. The upper and lower limits of the lower range, the range prescribed for "adelgids", listed on the Xytect WSP label were used.

\begin{tabular}{cc}
\hline Treatment Received & $\mathrm{g} \mathrm{Al} / 2.5 \mathrm{~cm} \mathrm{DBH}$ \\
\hline Untreated Control (UTC) & 0.00 \\
Soil Drench- Low & 0.67 \\
Soil Drench- High & 1.37 \\
Bark Application- Low & 0.67 \\
Bark Application- High & 1.37 \\
Bark Application + Adjuvant- Low* & 0.67 \\
Bark Application + Adjuvant- High* & 1.37 \\
\hline
\end{tabular}

Field Treatment

Soil injections were made through use of soil injector and bottle-pump (SPS Systems International, Santa Monica, CA.), while bark applications were applied through the use of a backpack sprayer (Greenwood ${ }^{T M}$ Camrillo, CA.). Equipment used is featured in Figure 14. No calibration was required for the bottle pump as the water level inside the container was visible, volume markings were clearly marked, and the container was in front of the technitian during use. Due to the nature of the backpack sprayer, calibration was required as it rested on the 
technitian's back. Calibration was performed between each treatments by averaging the time it took to fill a $0.24-\mathrm{L}$ container three times.

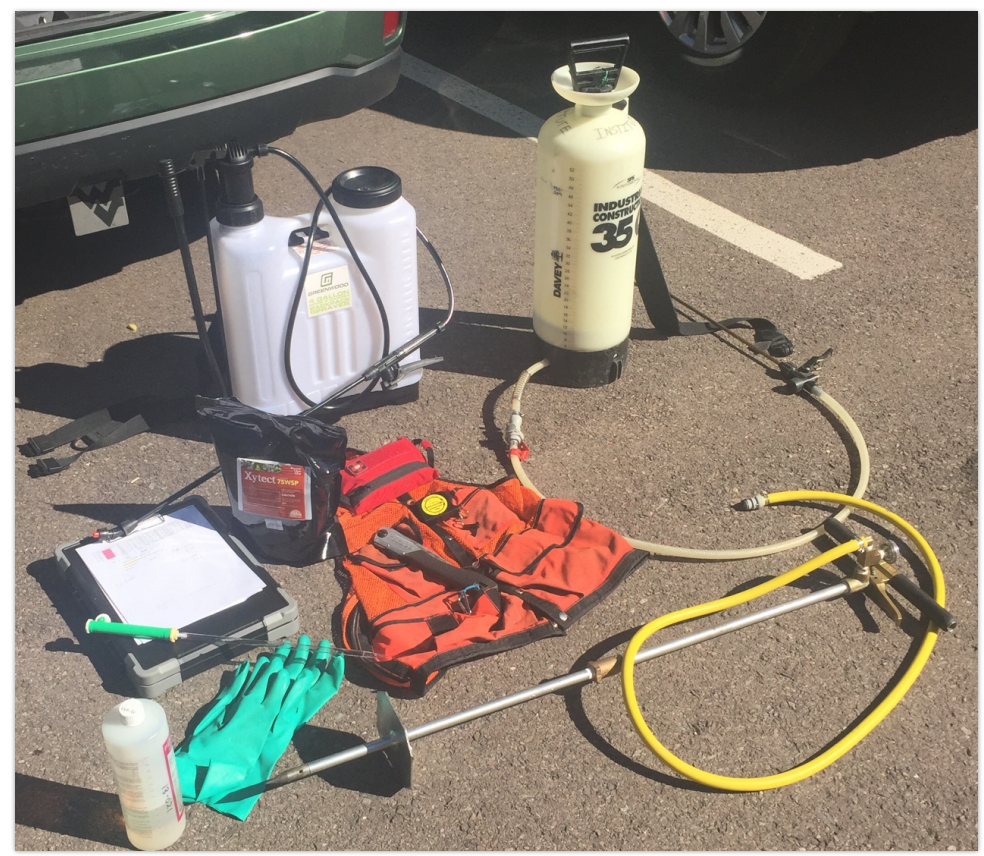

Figure 14: Application equipment used. Backpack and bottle sprayer are pictured in the rear. The soil injector laying across the foreground.

Xytect 75 WSP ${ }^{(R a i n b o w ~ T r e e c a r e ~ S c i e n t i f i c) ~ a n d ~ P e n t r a-b a r k ~}{ }^{\circledR}$ (Agbio, Inc.) were mixed in the containers and used for the insecticide treatments. Enough product was mixed to treat the eight trees determined to receive that particular treatment. Products were supplied by Rainbow Treecare Scientific and dosages can be found in Table 1.

Applications were made on May 12-13, 2017. With DBH measured prior to treatment, the required product amount for each tree was already calculated. Two technicians were used; one to operate the backpack sprayer and another to track the time it took to apply the product to an indvidual tree. Through calculating the volume of product required for each tree and calibrating the equipment prior to treatment, how long a technitian should be pumping the 
sprayer and applying product to the tree was known. Despite calibration, the back-sprayers did not maintain calibration well as some product remained at the end of each treatment. This remainder was divided evenly among the eight trees that recieved the same treatment.

\section{Hemlock Tissue Preperation \& Analysis}

Tissue samples were collected simultaneously with the population samples in November of 2017. Pole pruners were used to collect four samples from the tips of branches growing in the middle quadrant of the canopy. Branches from each tree were pooled in the bagging process and transferred to the lab on ice. The samples were transferred to paper bags, placed under a black bag and left in the dark to air dry for one week at $23.8^{\circ} \mathrm{C}$. Once dried, the needles were ground using a coffee grinder (Mr. Coffee ${ }^{\mathrm{TM}}$, Rye NY). UTC specimens were processed first, followed by the bark applications, and lastly soil applications. 99\% Isopropyl alcohol Kimwipes ${ }^{\circledR}$ were used to clean the ginder after each sample processed. $1.0 \mathrm{~g}$ of needle grindings was measured (Mettler Toledo, Zürich Switzerland) placed into $15 \mathrm{~mL}$ centrifuge tubes, labeled, kept in dark/dry conditions, and sent to Villanova University for processing.

To extract the imidacloprid and olefin, a 1:10 (needle:solvent) ratio of pulverized needle tissue $(1 \mathrm{~g})$ and acetonitrile $(10 \mathrm{~mL})$ were mixed in centrifuge tubes $(15 \mathrm{~mL})$, and shaken overnight on an orbital bench shaker (Model G33; New Brunswick Scientific, Edison, NJ). The supernatant acetonitrile was analyzed for imidacloprid and its metabolites by liquid chromatography tandem-mass spectrometry (LC/MS/MS).

Imidaclorpid and olefin quantification were conducted with a HPLC system comprised of binary Shimadzu LC-20AD pumps and a SIL-20A auto-sampler (Shimadzu, Colubia, MD). 
Analyst software controlled HPLC seperation (Applied BioSystems/SCIEX, Framingham, MA) run through a 2-mm Phenomenex Genini NX 2 mm guard column. An aqueous phase and organic mobile phase - water with 10-mM ammonium formate and acetonitrile - were used at a flow rate of $1.0 \mathrm{~mL} / \mathrm{min}$. A gradient elution ramped from 25 to $95 \%$ acetonitrile lasting one to eight minutes, used a column wash with $95 \%$ acetonitrile lasting eight minutes, and prior to the next injection performed a column stabilization period with $25 \%$ methanol. $10 \mu \mathrm{L}$ injections of imidacloprid and olefin standards were used for LC/MS/MS analysis.

A BioSystems/SCIEX 3200 Q - TRAP triple quadrupole mass spectrometer (Framingham, MA) was used to complete mass spetroscopy operating in positive eletrospray ionization mode (ESI). Table 2 sumarizes analytical MS precursor and fragment ions as well as the sensitivity of the LC/MS/MS mehod. Compound standards, outlined by Cook (2008), were analyzed in the ranges provided there. Standards were used to optimize multiple reaction monitoring transitions. Optimized electrospray ionization (ESI) source parameters were: curtain air gas 35 psi, Collision activated dissociation gas medium, ESI nebulizer gas 60 psi, auxilary gas $60 \mathrm{psi}$, ESI probe temperature $550 \mathrm{C}$, and ion spray voltage 5500V. Collision cell exit potential was set to $4 \mathrm{~V}$ and Q0 entrance potential to $10 \mathrm{~V}$. Q1 and Q3 resolution was set to high and dwell times for each transition was $500 \mathrm{~ms}$.

The limit of detection (LOD) for each compound was calculated at a signal-to-noise ratio of three basedbased off a low-conetration standard outline in Table 2. Using a 10- $\mu \mathrm{L}$ injection of each compound, LOD was converted to an on column mass LOD. Outpout was entered into Microsoft Excel (Microsoft, Redmond, WA) where datapoints below the respective LOD was given a zero value (E. P. Benton et al. 2015). 
Table 2: Precursor, fragment ions, and voltages for imidacloprid and olefin and analytical sensitivity

\begin{tabular}{lccccccc}
\hline Compound & $\begin{array}{c}\text { Precursor } \\
\text { ion }(\mathrm{m} / \mathrm{z})\end{array}$ & $\begin{array}{c}\text { Fragment } \\
\text { ion }(\mathrm{m} / \mathrm{z})\end{array}$ & $\begin{array}{c}\text { Declustering } \\
\text { Potential }(\mathrm{V})\end{array}$ & $\begin{array}{c}\text { Collision } \\
\text { energy } \\
(\mathrm{V})\end{array}$ & $\begin{array}{c}\text { Calibration } \\
\text { standard range } \\
(\mathrm{ppb})\end{array}$ & $\begin{array}{c}\text { LOD } \\
(\mathrm{ppb})\end{array}$ & $\begin{array}{c}\text { On-column } \\
\text { LOD }(\mathrm{pg})\end{array}$ \\
\hline Imidacloprid & 256.1 & 209.1 & 27 & 26 & $336-12.4$ & $0.4 \pm 0.1$ & $4.5 \pm 1.2$ \\
Olefin & 209.1 & 205.1 & 26 & 27 & $321-11.9$ & $1.0 \pm 0.3$ & $10.5 \pm 3.2$ \\
\hline
\end{tabular}

HWA Population Counts \& Mortality

Three HWA insect population counts were conducted. The first was collected in the field on May 11, 2017 (pre-treatment), the second on November 20, 2017 (6-months post-treatment), and the last the on April 12, 2018 (11-months post-treatment). Collection was conducted by dividing the canopy into twelve quadrants, three vertically, and four radially. One $10 \mathrm{~cm}$ distal branch tip was collected from each quadrant using a Marvin Pole pruner, bagged, labeled, and brought to the lab on ice where it they were stored in the fridge at $4{ }^{\circ} \mathrm{C}$.

During the May 2017 count, strictly egg masses were tallied. For the November 2017 and May 2018 it was decided all stages of life were to be counted. Tallies were made using a steroscope (Leica Zoom 2000; Leica, Wetzlar, Germany) and probe that was used to ellicit movement. When no movement was observed the adelgid was punctured to observe bright hemolymph. If dry, lifeless, or full of black hemolymph, insects were considered dead. Percent mortality was calculated for each group where possible. The use of Abbott's correction formula (Abbott 1925) took the natural mortality rate found in the uncreated control (UTC) and factored this into the mortality of the treated groups. 


\section{Cofactor Measurement}

In order to account for variation in concentration levels, diameter at breast height (DBH), live crown ratio (LCR), soil moisture and precipitation quantities were recorded when trees were originally identified. Volumetric soil moisture data was measured through use of a time domain reflectrometer (Model CS605, Campbell Scientific 2001). Out of the fifty-six treated trees, thirteen were randomly selected to receive soil moisture readings twice monthly between the months of June 2017 and November 2017. Three readings were taken from inside the dripline of these thirteen trees and then averaged. The daily max, min, and precipitation was recorded to account for variation in mortality rates and was accessed through the nearest NOAA station in Confluence, PA ( $\sim 14 \mathrm{~km}$ miles away). This data can be found in the appendix.

\section{Financial Comparison}

Comparisons between soil injections and bark applications were calculated on a per tree basis requiring data points found in Figure 14. The national mean wage of Arborists (\$18.55/hour) was used in the total cost calculation and was taken from the United States Department of Labor website (BLS 2017). Calibration and mixing time were incoporated into this calculation. Product prices differ year to year, between suppliers, with the quantity ordered, between brands, between formulations withing brands, and the amount of active ingredient within formulations. Product prices used for Xytect 75 WSP ${ }^{\circledR}$ and Pentra-bark ${ }^{\circledR}-\$ 3.86 / 29 \mathrm{~mL}$ and $\$ 1.65 / 29 \mathrm{~mL}$ respectively- were obtrained from two suppliers and averaged. Earlier it was mentioned two technicians were used during field treatment. The second technitian ensured the first technitian was adhering to the time required for the proper dosage to be applied to an 
individual tree. It is important to note this does not include time manuevering around the

branches of an individual tree or from tree to tree as there was terrain variability of all sites.

$$
\begin{gathered}
\text { Treatment Cost }(\$)=\left[\text { application time }(s)+\left(\frac{\text { calibration time }(s)+\text { mixing time }(s)}{8}\right) *\right. \\
\$ \text { labor } / s]+[(\text { Xytect applied }(m L) * \$ \text { Xytect } / m L)+(\text { Pentrabark applied }(m L) * \\
\$ \text { Pentrabark } / m L)]
\end{gathered}
$$

Formula 1: Financial comprison formula. Cost was simply computed by totaling the labor and product costs on a per tree basis. The formula above shows exactly how these costs were calculated. One calculated, the individual costs were analysed using orthognal contrasts. To obtain an accurate estimate of how long application took, the length of time required calibrate and mix the product was incorporated by averaging this over the eight trees that received the same treatment. The average cost of Xytect WSP \& Pentra-bark used was $\$ 3.86 / 29 \mathrm{~mL} \& \$ 1.65 / 29 \mathrm{~mL}$ and $\$ 0.31 /$ second was used for the cost of labor. " $\mathrm{s} "=$ seconds

\section{Statistical Analysis}

To facilitate the analyses of imidacloprid and olefin tissue concentration and biological efficacy, treatments were arranged in a 3x2 factorial fashion, with the addition of the UTC. This allowed for the use of orthognal contrasts in analyzing the tissue concentrations mortality rates, and financial efficacy. The use of contrasts was intended to reduce the Type I error rate. Contrasts performed were: 1.) UTC vs all treated trees 2.) soil treatments vs. bark treatments.) low dosage vs. high dosage and 4.) bark treatments vs. bark + Pentra-bark ${ }^{\circledR}$ treatments. Data required a $\log +1$ transformation to obtain a normal distribution while population counts followed a negative binomial distribution that, by nature, transforms data using a log function. Goodness of fit was assessed by chi-square per degress of freedom and all were less than one, indicating a good fit. The PROC GLM and GLIMMIX functions of SAS ${ }^{\circledR}$ were used respectively for analyses (SAS®, Version 9.4, SAS Institute Inc., Cary, NC). DBH and LCR influence on imidacloprid and olefin concentrations was examined through an ANCOVA analysis through the 
PROC GLM feature as well. Analyses were performed through JMP ${ }^{(J M P}{ }^{\circledR}$, Version Pro 12.2, SAS Institute Inc., Cary, NC). Significance criterion alpha for all tests was 0.05 .

\section{Results}

Tissue Analysis

All insecticide treatments produced detectable levels concentrations of imidacloprid and olefin. Means were not significantly affected (Table 4$)$ by the labeled dosage $(\mathrm{P}=0.1181)$ or the presence of an adjuvant $(\mathrm{P}=0.8358)$. No significant differences were found between bark treatments and soil treatments $(\mathrm{P}=0.0789)$. All treatments were significantly different from the UTC in regards to imidacloprid $(\mathrm{P}<0.0001)$ and olefin $(\mathrm{P}=0.0376)$.

Table 3: One-way ANOVA with orthogonal contrasts of the mean consentration $\pm S E$ (standard error) testing effect of untransformed imidacloprid \& olefin concentrations. * indicate significant differences.

\begin{tabular}{|c|c|c|c|c|c|}
\hline \multirow[b]{2}{*}{ Comparison } & \multirow[b]{2}{*}{$\mathrm{N}$} & \multicolumn{2}{|c|}{ Imidacloprid (ppb) } & \multicolumn{2}{|c|}{ Olefin $(p p b)$} \\
\hline & & Mean \pm SE & $\operatorname{Pr}>|t|$ & Mean $\pm \mathrm{SE}$ & $\operatorname{Pr}>|t|$ \\
\hline $\begin{array}{l}\text { UTC vs. } \\
\text { Treated }\end{array}$ & $\begin{array}{c}8 \\
48\end{array}$ & $\begin{array}{c}0.00 \pm 0.00 \\
85.12 \pm 24.33\end{array}$ & $<.0001 *$ & $\begin{array}{c}0.00 \pm 0.00 \\
10.64 \pm 2.93\end{array}$ & $0.0376 *$ \\
\hline $\begin{array}{l}\text { Soil vs. } \\
\text { Bark }\end{array}$ & $\begin{array}{l}16 \\
32\end{array}$ & $\begin{aligned} 161.95 & \pm 68.55 \\
46.70 & \pm 8.19\end{aligned}$ & 0.0789 & $\begin{array}{c}19.69 \pm 7.78 \\
6.12 \pm 9.66\end{array}$ & 0.2121 \\
\hline $\begin{array}{l}\text { Low vs. } \\
\text { High Dosage }\end{array}$ & $\begin{array}{l}24 \\
24\end{array}$ & $\begin{array}{l}91.18 \pm 45.20 \\
79.06 \pm 19.34\end{array}$ & 0.1181 & $\begin{array}{c}13.31 \pm 4.59 \\
7.97 \pm 3.80\end{array}$ & 0.5013 \\
\hline $\begin{array}{c}\text { Bark vs. } \\
\text { Bark + Pentra-bark }\end{array}$ & $\begin{array}{l}16 \\
16\end{array}$ & $\begin{array}{l}44.15 \pm 10.46 \\
49.25 \pm 12.94\end{array}$ & 0.8358 & $\begin{array}{c}5.59 \pm 2.18 \\
6.652 .69\end{array}$ & 0.7721 \\
\hline
\end{tabular}




\section{Biological Efficacy}

Contrasts of live adults in the spring 2017 ( $\mathrm{P}=0.8799)$, fall 2017( $\mathrm{P}=0.0155)$, and spring 2018 ( $\mathrm{P}=0.9817$ ) found no significant differences between groups prior to treatment (spring 17), significant differences between the UTC and treated specimens for the fall of 2017, and no differences in the spring of 2018 (Table 5). Meanwhile, the mortality comparisons between the fall 2017 and spring 2018 counts reveal: that morality across all groups in the fall was high (Figure 15), there was a significant difference between morality in the soil and bark treated groups in the fall of $17(\mathrm{P}=0.0384$, Table 6$)$, morality increased from the fall to spring across all groups yielding no difference between the soil/bark treatments in the spring $(\mathrm{P}=0.0855)$, and the UTC mortality decreased from fall to spring.

Table 4: One-way ANOVA with orthogonal contrasts of live adults in the spring 2017 (Time = 0 months), fall 2017 (Time $=6$ months), \& spring 2018 (Time $=11$ months) Findings include no significant differences were found pretreatment (spring 17), significant differences between the UTC and treated specimens fall 2017), and no differences in the spring of 2018.

\begin{tabular}{|c|c|c|c|c|c|c|c|}
\hline \multirow[b]{2}{*}{ Comparison } & \multirow[b]{2}{*}{$\mathrm{N}$} & \multicolumn{2}{|c|}{ Spring 17} & \multicolumn{2}{|c|}{ Fall 17} & \multicolumn{2}{|c|}{ Spring 18} \\
\hline & & Mean \pm Error & $\operatorname{Pr}>|t|$ & Mean \pm Error & $\operatorname{Pr}>|t|$ & Mean \pm Error & $\operatorname{Pr}>|t|$ \\
\hline $\begin{array}{l}\text { UTC vs. } \\
\text { Treated }\end{array}$ & $\begin{array}{c}8 \\
48\end{array}$ & $\begin{array}{c}8.62 \pm 4.86 \\
15.12 \pm 5.74\end{array}$ & 0.8799 & $\begin{array}{c}99.12 \pm 45.22 \\
19.81 \pm 5.47\end{array}$ & $0.0155^{*}$ & $\begin{array}{l}0.62 \pm 0.26 \\
2.33 \pm 1.32\end{array}$ & 0.9817 \\
\hline $\begin{array}{l}\text { Soil vs. } \\
\text { Bark }\end{array}$ & $\begin{array}{l}16 \\
32\end{array}$ & $\begin{array}{c}18.78 \pm 12.79 \\
12.93 \pm 5.24\end{array}$ & 0.5751 & $\begin{aligned} 36.33 & \pm 11.91 \\
9.90 & \pm 4.32\end{aligned}$ & $0.0216^{*}$ & $\begin{array}{l}1.05 \pm 0.73 \\
3.10 \pm 2.07\end{array}$ & 0.9778 \\
\hline $\begin{array}{l}\text { Low vs. } \\
\text { High Dosage }\end{array}$ & $\begin{array}{l}24 \\
24\end{array}$ & $\begin{aligned} 23.58 & \pm 11.00 \\
6.66 & \pm 2.73\end{aligned}$ & $0.0241^{*}$ & $\begin{array}{l}22.95 \pm 7.78 \\
16.66 \pm 7.81\end{array}$ & 0.2428 & $\begin{array}{l}4.00 \pm 2.57 \\
0.66 \pm 0.54\end{array}$ & 0.9861 \\
\hline $\begin{array}{c}\text { Bark vs. } \\
\text { Bark + Pentra-bark }\end{array}$ & $\begin{array}{l}16 \\
16\end{array}$ & $\begin{array}{c}14.71 \pm 10.41 \\
11.37 \pm 4.12\end{array}$ & 0.5213 & $\begin{array}{c}8.85 \pm 3.82 \\
10.81 \pm 7.52\end{array}$ & 0.9455 & $\begin{array}{l}0.07 \pm 0.07 \\
5.57 \pm 3.81\end{array}$ & 0.9747 \\
\hline
\end{tabular}




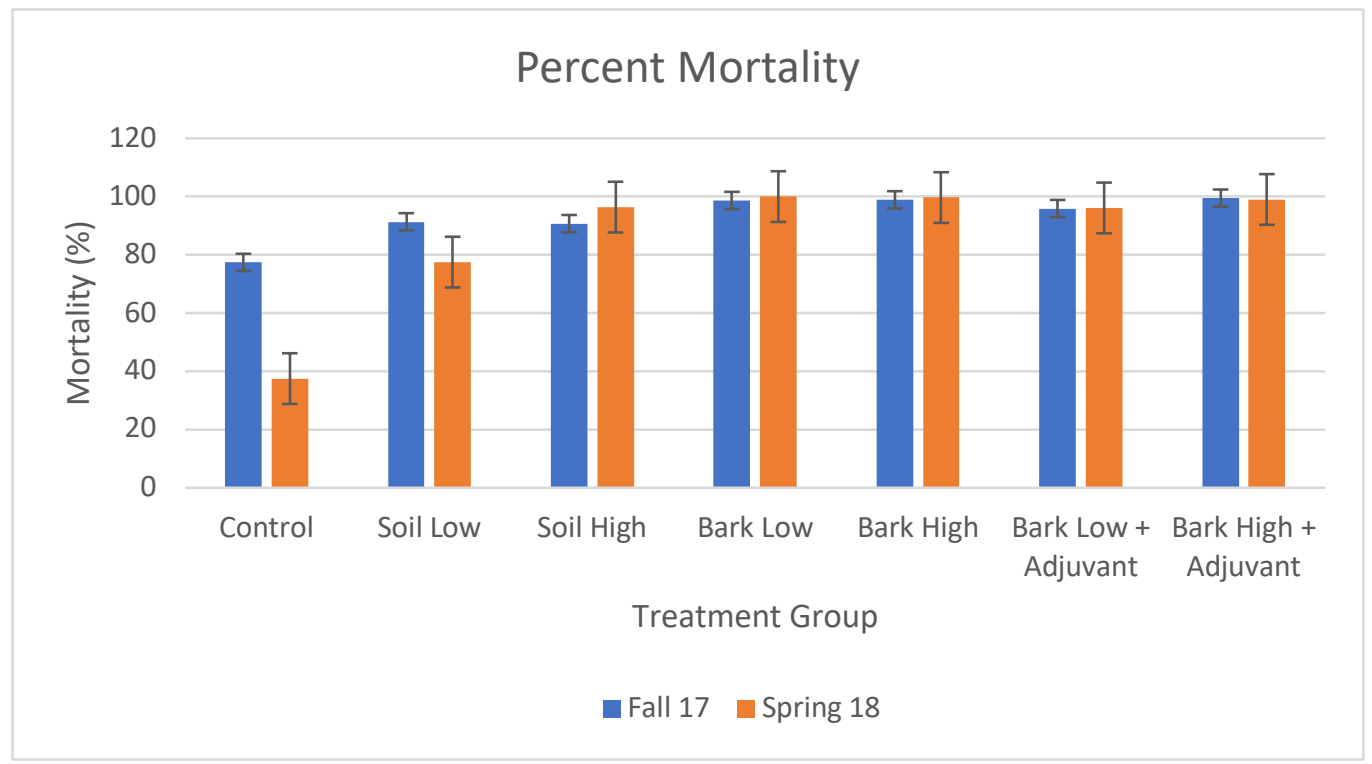

Figue 16: Percent mortality for each count where the total number of adelgid across all life stages were collected. The use of Abbott's formula adjusts for the percent mortality experienced by UTC (Abbott 1925). Results show mortality decreased from the fall to spring in the UTC, while the morality between the the soil and bark treatments were significantly different in the fall. Come spring, these differences between to the soil and bark treatments was reduced.

Table 5: Mortality contrasts show signficant differences in fall mortalitiy between the UTCcontrol and the treated groups. Differences occur between the untreated and treated groups for both counts, and between soil/bark treatments for the fall of 2017. This difference no longer exists by the spring.

Fall 17

Spring 18

\begin{tabular}{|c|c|c|c|c|c|}
\hline Comparison & $\mathrm{N}$ & Mean \pm Error & $\operatorname{Pr}>|t|$ & Mean \pm Error & $\operatorname{Pr}>|t|$ \\
\hline $\begin{array}{l}\text { UTC vs. } \\
\text { Treated }\end{array}$ & $\begin{array}{c}8 \\
48\end{array}$ & $\begin{array}{c}20.74 \pm 0.19 \\
80.28 \pm 69.28\end{array}$ & $<.0001^{*}$ & $\begin{array}{c}37.50 \pm 12.50 \\
80.97 \pm 7.75\end{array}$ & $0.0025^{*}$ \\
\hline $\begin{array}{l}\text { Soil vs. } \\
\text { Bark }\end{array}$ & $\begin{array}{l}16 \\
32\end{array}$ & $\begin{array}{l}57.60 \pm 0.19 \\
91.62 \pm 3.92\end{array}$ & $0.0384 *$ & $\begin{array}{l}48.8 \pm 21.33 \\
97.05 \pm 1.22\end{array}$ & 0.0855 \\
\hline $\begin{array}{c}\text { Low vs. } \\
\text { High Dosage }\end{array}$ & $\begin{array}{l}24 \\
24\end{array}$ & $\begin{array}{c}77.76 \pm 8.40 \\
82.79 \pm 35.00\end{array}$ & 0.7490 & $\begin{array}{c}65.66 \pm 14.81 \\
96.28 \pm 2.39\end{array}$ & 0.2365 \\
\hline $\begin{array}{c}\text { Bark vs. } \\
\text { Bark + Pentra-bark }\end{array}$ & $\begin{array}{l}16 \\
16\end{array}$ & $\begin{array}{l}94.21 \pm 2.76 \\
89.03 \pm 7.41\end{array}$ & 0.7803 & $\begin{array}{l}99.61 \pm 0.33 \\
94.4 \pm 2.280\end{array}$ & 0.8987 \\
\hline
\end{tabular}




\section{Financial Efficacy}

Significant cost differences exist (Table 7) between the UTC versus all insecticide treatments $(\mathrm{P}=0.0015)$, and insecticide treatments of the low and high dosages $(\mathrm{P}=0.0004)$ in which the high dose was $32 \%$ higher in cost. No differences of cost were found between soil versus bark treatments $(0.1194)$ or bark versus bark + Pentra-bark $®(0.1009)$.

Table 5: Financial contrast found differences between UTC/all treatments and low/high dosages while no differences exist between the soil/bark treatments and bark/bark + Pentra-bark treatments.

\begin{tabular}{cccc}
\hline Comparison & $\mathrm{N}$ & Mean Cost $(\$) \pm$ Error & $\operatorname{Pr}>|\mathrm{t}|$ \\
\hline UTC vs. & 8 & $0.00 \pm 0.00$ & $0.0015^{*}$ \\
Treated & 48 & $1.79 \pm 0.07$ & \\
Soil vs. & 16 & $1.77 \pm 0.15$ & 0.1194 \\
Bark & 32 & $1.80 \pm 0.08$ & $0.0004^{*}$ \\
Low vs. & 24 & $1.55 \pm 0.09$ & 0.1009 \\
High Dosage & 24 & $2.04 \pm 0.10$ & \\
Bark vs. & 16 & $1.68 \pm 0.10$ & \\
Bark + Pentra-bark. & 16 & $1.91 \pm 0.13$ & \\
\hline
\end{tabular}

\section{Cofactors}

Soil moisture appeared to be adquate across the site for plant growth in the silt loams of the site. In silt loams, water is available when percentages are above $14 \%$ and all measurements were above this level. This is explained, in part, by the amount of rainfall experienced in the area (Appendix). From these averages, a lack of available water did not inhibit water uptake and, in turn, imidacloprid translocation (Table 8 and Figure 16). The average monthly minimum temperatures ranged from $1.11^{\circ} \mathrm{C}$ to $-10.98^{\circ} \mathrm{C}$ between the coldest months of November through March (Appendix). 
Table 7: Percent soil moisture was collected twice monthly with TDR on a sub-sample of trees and averaged.

\begin{tabular}{cc}
\hline Month (2017) & \% Soil Moisture \\
\hline June & 19.65 \\
July & 22.26 \\
August & 16.80 \\
September & 14.80 \\
October & 23.93 \\
November & 23.86 \\
\hline
\end{tabular}

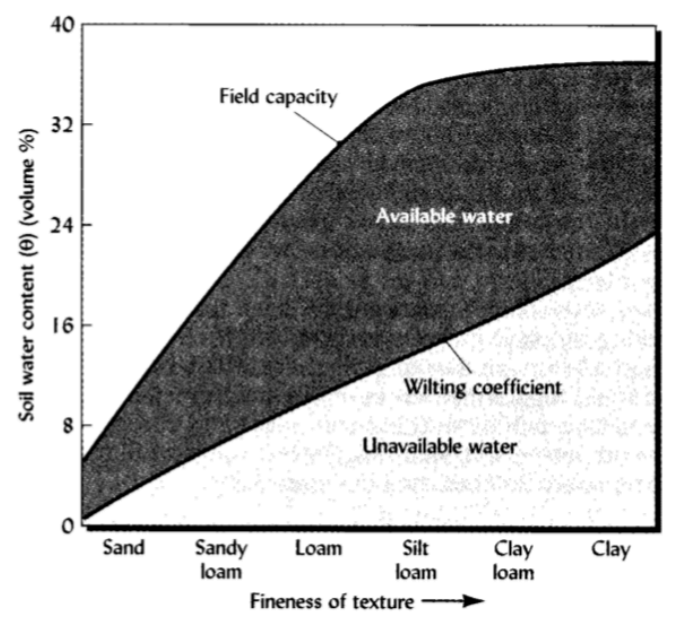

Figure 17: Monthly averages found in Table 8, fell within the avaiable water band band for the silt loams of the site. Water up-take and imidacloprid translocation were not of detriment to the product. Graph from Bradley \& Weil 1999.

$\mathrm{DBH}$ was found to have an effect on the tissue concentrations of imidacloprid ( $\mathrm{P}=$ $0.0167, \mathrm{R}^{2}=0.4452$, Figure 18 ). Regression equations for the treatments are: soil low $=4.87$ $0.05 * \mathrm{DBH}$, soil high $=7.34-0.22 * \mathrm{DBH}$, bark low $=6.34-0.23 * \mathrm{DBH}$, bark high $=6.02-0.24 * \mathrm{DBH}$, bark low + pentra-bark $=5.71-0.24 * \mathrm{DBH}$, and bark high + pentra-bark $=4.24+0.00 * \mathrm{DBH}$. Meanwhile DBH had no effect on olefin concnetrations $(\mathrm{P}=0.1580)$. LCR was not found to have an effect on the concentration of either compound tested; imidicloprid $(\mathrm{P}=0.2068)$ or olefin $(\mathrm{P}=0.1224)$. 


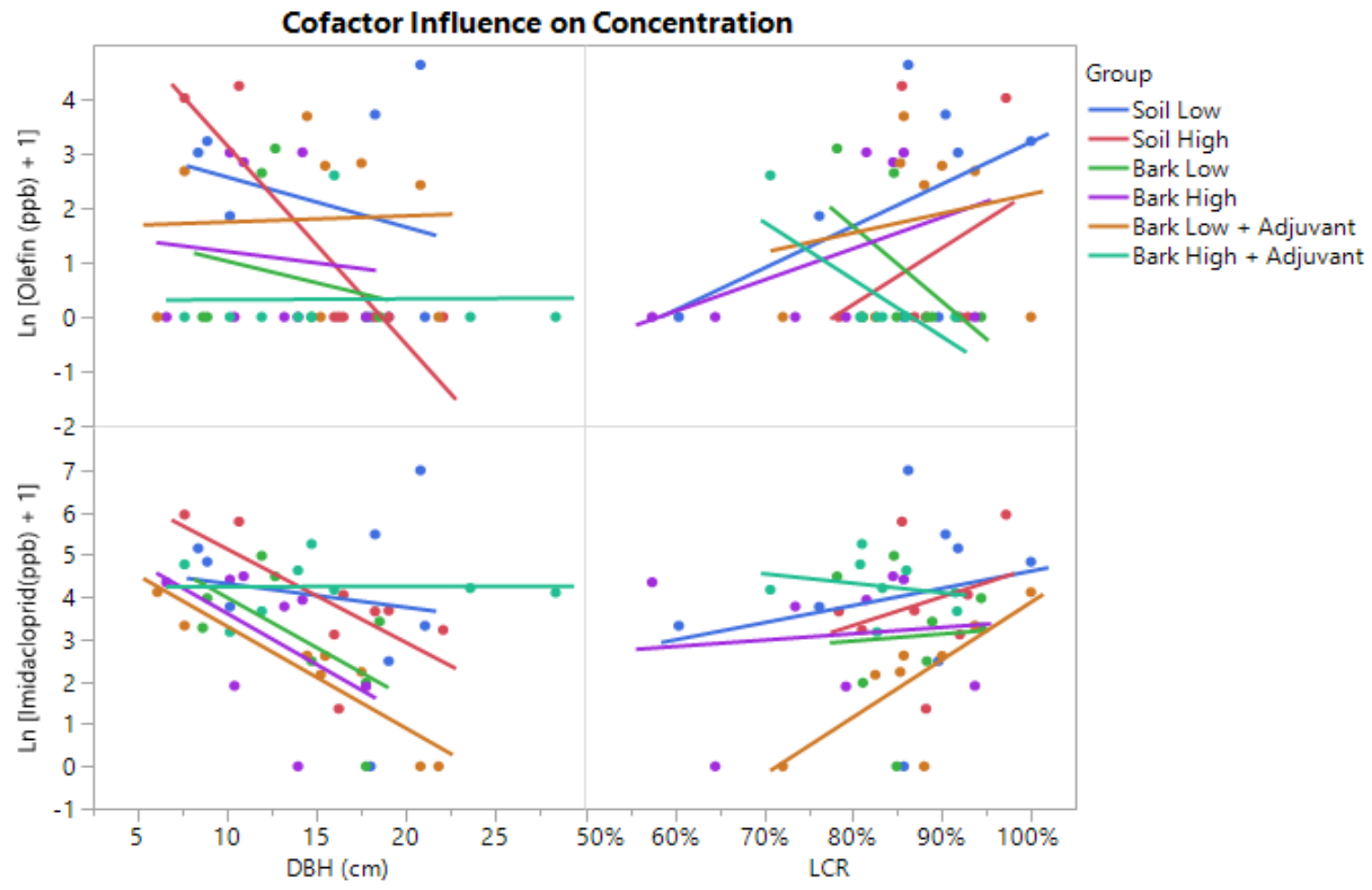

Figure 18: Tissue concentration and cofactor relationships. DBH was the only cofactor to influence the concentration of either compound (DBH, $P=0.0167)$. As DBH increases, tissue concentrations of imidacloprid are reduced, as noted in several studies.

\section{Discussion}

This study was designed to investigate whether basal bark applications of imidacloprid can be used to treat HWA rather than other application methods. Before proceeding, it is important to adress variability within the data enumerated in Table 3 and the Appendix.

Significant varibility existed among several treatments, in particular the soil low treatment. This was due to an oulier three times the standard deviation. Varability in the bark treatments may partly exist due to the inability of equipment to maintain the calibration established as mentioned earlier.

Results suggest imidacloprid basal bark applications may be added as one more tool in an IPM technician's arsenal when treating for HWA. This study found basal bark applications 
produce imidacloprid and olefin tissue concentrations similar to those associated with soil injections. In addition, concentrations were similar to those found in other studies, despite different application methods (Turcotte 2015, Cowles and Lagalante 2009, Benton et al. 2016). In one instance, where bark applications were also used, imidacloprid concenrations obtained in this study appear to be higher (McCullough et al. 2011). Bark penetration was not influenced by labeled dosage or the presence of Pentra-bark ${ }^{\circledR}$. Findings also suggest HWA mortalitiy of bark applications is comprable to soil injections and may produce higher levels of mortality in a shorter timespan, after which it levels off.

These results are not suprising for many reasons. Imidacloprid is one of several neonictinoids that are water soluable and have been proven (as a class of insecticides) to work as a basal bark spray providing sufficient insecticide concentrations for bark penetration and suffecient insect mortality (Cowles 2010). It is the water solubility that, at least in part, dictates the penetrating abilities of a chemical. The addition of an adjuvant in this study was not found to increase the concentrations of imidacloprid or olefin, nor lead to greater mortality. Results of the adjuvant efficacy corraborate the findings of both Cowles (2010) and McCullough (2011), suggesting that there is little reason to Pentra-bark ${ }^{\circledR}$ adjuvant in basal bark applictions for HWA. This is not to say it does not work with other pesticides for other pests. On the other hand, bark treatments + Pentra-bark ${ }^{\circledR}$ were not any more epensive than bark treatments lacking Pentrabark ${ }^{\circledR}$ or their soil injection counterparts.

The cofactors observed, DBH \& LCR, were only observed to influence imidacloprid concentrations. As other studies have noted (Turccotte et al. 2016, Ford et al. 2010) the concentration decreases as DBH increases due to the fact water usage is exponentially related to 
DBH. This means smaller trees use proportionally less water than their larger counterparts (Ford et al. 2010). Future researchers may wish to investigate if dose should be adjusted with DBH.

Mortality was found to be significantly higher in the bark treatments over the soil treatments during the fall of 2017 the, but not different in the spring of 2018. This difference was found despite the lack of significant difference in concentrations of imacloprid or olefin in the tissue samples taken in the fall. The quick mortality by basal bark applications was unexpected, however, it is plausible that the insecticide can enter the xylem more quickly as it is not as dependant on soil moisture for uptake (Norris 1967). These results vary slightly from previous research conducted by Faulkenberry (2012) whose study found that at apprximately six months post treatment, mortality between imidacloprid bark applications and soil drenches did not significantly differ. It should be noted that the Faulkenberry reseach did not utilize a correction for natural mortality such as Abbott's correction formula. Future research could investigate whether imidacloprid bark applications move more quickly into the xylem by sampling tissues throughout the growing season. Parker (1998) established that HWA coldhardiness dimishes over the cold months as March approaches and that prolonged cold temperatures of $-20^{\circ} \mathrm{C}$ can impact HWA populations (Cost et al. 2008). The monthly mean minimum temperature reached lowest temperatures in the month of January, with an average of $-10^{\circ} \mathrm{C}$. These temperatures could have contributed to the increase of mortalitiy across the treatments.

While the cost for the bark applications of imidacloprid was not found to differ from that of soil applications, having the bark application in the IPM toolbox allows additional flexibility. Additionally, since there was no difference between the high and low rate of imidacloprid in terms of tissue conentration and mortality, using a lower does could reduce cost by approximately $32 \%$. 
These savings could potentially be reduced further. Norris (1967) suggests that bark applications may require $1 / 10^{\text {th }}$ to $1 / 15^{\text {th }}$ the amount of product compared to other application methods. Similarliy, mixing imidacloprid with less water could result in higher tissue concentrations, as during application, some of the insecticidal mixture runs down the bark and onto the soil. By increasing the concentration of the imidacloprid/water mixture, perhaps less water can be used, tissue concentrations may be higher, application times could be shorter, and applications less costly.

The data seems to suggest, if the bark application method was added to the product label, arborists could have a product that is comparable to the soil injections commonly used in terms of insecticidal concentrations, insect mortality, and cost. If approved, bark applications are another application method that yield comprable results with some additional benefits, making the use of this method a decision of practicality. In the meantime, more details about this method can be probed.

Researchers may also wish to test on stands with a higher HWA population. The trees in this study had a relatively low level of HWA infestation. Population surveys had not been conducted previously. With no quantative data, prior infestation rates are unknown. If significant populations had existed at one point, they most likely were reduced by several winters with prolonged periods of below freezing temperatures. Thirdly, the long-term effects of bark treatments should be studied in regards to longevity, tissue concentration, and mortality rates. With such a high natural mortality rate present in the UTC and such a small number of living insects, it may be adviseable to conduct research on stands with a more dense population to get a clearer picture of just how this application method affects pest populations. Lastly, with a wide 
variety of backpack sprayers available for purchase, investigation into reliable models, brands, or measurement equipment should be pursued for scientific and commercial use. 


\section{Works Cited}

Abbott, W.S. 1925. A Method of Computing Effectiveness of an Insecticide. Journal of the American Mosquito Control Association Vol.3 No. 2.

Bayer Environmental Science. 2017. CoreTect ${ }^{\mathrm{TM}}$ Product Label.

Benton, E., J. F. Grant, R. Cowles, J. Webster, R. Nichols, A. Lagalante, and C. Coots. 2016. Assessing Relationships Between Tree Diameter and Long-Term Persistence of Imidacloprid and Olefin to Optimize Imidacloprid Treatments on Eastern Hemlock. Forest Ecology and Management 370: 12-21.

Benton, E. P., J. F. Grant, R. J. Webster, R. J. Nichols, R. S. Cowles, A. F. Lagalante, and C. I. Coots. 2015. Assessment of Imidacloprid and Its Metabolites in Foliage of Eastern Hemlock Multiple Years Following Treatment for Hemlock Woolly Adelgid, Adelges tsugae (Hemiptera: Adelgidae), in Forested Conditions. Journal of Economic Entomology 108 (6): 2672-2682.

Burns, Russell M., and Honkala, Barbara H. 1990. Silvics of North America: Volume 1. Conifers. United States Department of Agriculture (USDA), Forest Service, Agriculture Handbook 654.

Brady, N. C, and R. R Weil. 1999. The Nature and Properties of Soils. Upper Saddle River, NJ: Prentice Hall.

Casida, John E., and Kathleen A. Durkin. 2013. Neuroactive Insecticides: Targets, Selectivity, Resistance, and Secondary Effects. Annual Review of Entomology 58: 99-117.

Cheah, Carole, Michael E. Montgomery, Scott Salom, Bruce L. Parker, Scott Costa, and Margaret Skinner. 2004. "Biological Control of Hemlock Woolly Adelgid. United States Department of Agriculture, Forest Service, Forest Health Technology Enterprise Team, Morgantown 22. 
Coots, Carla, Paris Lambdin, Jerome Grant, and Rusty Rhea. 2013. Spatial and Temporal Distribution of Residues of Imidacloprid and Its Insecticidal 5-Hydroxy and Olefin and Metabolites in Eastern Hemlock (Pinales: Pinaceae) in the Southern Appalachians. Journal of Economic Entomology 106 (6): 2399-2406.

Costa, Scott D.; Trotter, R. Talbot; Montgomery, Michael; Fortney, Michael. 2008. Low temperature in the hemlock woolly adelgid system. In: Onken, Brad; Reardon, Richard, comps. Fourth Symposium on hemlock woolly adelgid in the eastern United States; 2008 February 12-14; Hartford, CT. FHTET 2008-01. Morgantown, WV: U.S. Forest Service, Forest Health Technology Enterprise Team: 47-52.

Cowles, R. S., and C. A. S. J. Cheah. 2002. Foliar Sprays for Control of Hemlock Woolly Adelgid, 2001. Arthropod Management Tests 27 (1).

Cowles, Richard S. 2009. Optimizing Dosage and Preventing Leaching of Imidacloprid for Management of Hemlock Woolly Adelgid in Forests. Forest Ecology and Management 257 (3): 1026-1033.

Cowles, Richard S. 2010. Optimizing a Basal Bark Spray of Dinotefuran to Manage Armored Scales (Hemiptera: Diaspididae) in Christmas Tree Plantations. Journal of Economic Entomology 103 (5): 1735-1743.

Cowles, Richard S., and Anthony F. Lagalante. 2009. Activity and Persistence of Systemic Insecticides for Managing Hemlock Woolly Adelgids.

Dilling, Carla, Paris Lambdin, Jerome Grant, and Rusty Rhea. 2009. Community Response of Insects Associated with Eastern Hemlock to Imidacloprid and Horticultural Oil Treatments. Environmental Entomology 38 (1): 53-66.

Dirr, Michael. 1998. Manual of Woody Landscape Plants: Their Identification, Ornamental Characteristics, Culture, Propagation and Uses. Champaign, Ill.: Stipes Pub.

Eisenback, Brian M., Scott M. Salom, Loke T. Kok, and Anthony F. Lagalante. 2014. Impacts of Trunk and Soil Injections of Low Rates of Imidacloprid on Hemlock Woolly Adelgid 
(Hemiptera: Adelgidae) and Eastern Hemlock (Pinales: Pinaceae) Health. Journal of Economic Entomology 107 (1): 250-258.

Elbert, Alfred, Matthias Haas, Bernd Springer, Wolfgang Thielert, and Ralf Nauen. 2008. Applied Aspects of Neonicotinoid Uses in Crop Protection. Pest Management Science 64 (11): 1099-1105.

Evan L. Preisser, Kelly L.F. Oten, and Fred P. Hain. 2014. Hemlock Wolly Adelgid in the Eastern United States: What Have We Learned? Southeastern Naturalist.

Fidgen, Jeffrey G., David E. Legg, and Scott M. Salom. 2006. Binomial Sequential Sampling Plan for Hemlock Woolly Adelgid (Hemiptera: Adelgidae) Sistens Infesting Individual Eastern Hemlock Trees. Journal of Economic Entomology 99 (4): 1500-1508.

Faulkenberry, Mark S., Culin, Joseph D., Jeffers, Steven N., Riley, Melissa B., Bridges, and William C. 2012. Efficacy of Imidacloprid and Dinotefuran Applied as Soil Drenches or Trunk Sprays for Managing Adelges tsugae (Hemiptera: Adelgidae) on Mature Hemlock Trees in a Forest. Journal of Entomological Science, 47(4):369-374.

Ford, Chelcy R., Barbara C. Reynolds, James M. Vose, and others. 2010. Xylem Transport Models Optimize Effectiveness of Systemic Insecticide Applications for Controlling Hemlock Woolly Adelgid (Adelges tsugae). 120. US Department of Agriculture, Forest Service, Southern Research Station.

Guy Nesom. 2000. Eastnern Hemlock. United States Department of Agriculture Natural Resources Conservation Service.

Havill, Nathan P., Michael E. Montgomery, Guoyue Yu, Shigehiko Shiyake, and Adalgisa Caccone. 2006. Mitochondrial DNA from Hemlock Woolly Adelgid (Hemiptera: Adelgidae) Suggests Cryptic Speciation and Pinpoints the Source of the Introduction to Eastern North America. Annals of the Entomological Society of America 99 (2): 195203. 
Havill, Nathan P., Lígia C. Vieira, and Scott M. Salom. 2014. Biology and Control of Hemlock Woolly Adelgid. US Dep. Agric. For. Serv. For. Health Technol. Ent. Team, FHTET2014-05, Morgantown, WV.

Hokkanen, Heikki M. T. 2015. Integrated Pest Management at the Crossroads: Science, Politics, or Business (as Usual)? Arthropod-Plant Interactions 9 (6): 543-45.

International Untion for Conservation of Nature. 2011. Tsuga canadensis: Farjon, A.: The IUCN Red List of Threatened Species 2013: E.T42431A2979676. International Union for Conservation of Nature.

Johnson, Warren T. 1985. Horticultural Oils. Journal of Environmental Horticulture 3 (4): 188191.

Joseph, Shimat V., S. Kristine Braman, Jim Quick, and James L. Hanula. 2011. The Range and Response of Neonicotinoids on Hemlock Woolly Adelgid, Adelges tsugae (Hemiptera: Adelgidae). Journal of Environmental Horticulture 29 (4): 197-204.

Kristen L. Wickert. 2016. Biology, Ecology and Efficacy of Lecanicillium Muscarium as a Potential Fungal Biocontrol of the Invasive Hemlock Woolly Adelgid (Adelges tsugae) on Eastern Hemlock (Tsuga canadensis).

Lagalante, Anthony F. 2008. Analytical Aproaches to Imidacloprid and Metabolite Analysis. Proceedings, pp. 92-94. In B. Onken and R. Reardon (eds.), Fourth symposium on hemlock woolly adelgid in the Eastern United States; Hartford, CT. Department of Agriculture, Forest Service, Forest Health Technology Enterprise Team, Morgantown, WV.

Lagalante, Anthony F., and Peter W. Greenbacker. 2007. Flow Injection Analysis of Imidacloprid in Natural Waters and Agricultural Matrixes by Photochemical Dissociation, Chemical Reduction, and Nitric Oxide Chemiluminescence Detection. Analytica Chimica Acta 590 (2): 151-158. 
Lamb, Elizabeth, Dan Gilrein, Ronald Gardner, Michael Helms, and Lea Loizos. 2011. 2011 Cornell Pest Management Guide for Commercial Production Ainid Maintenance of Trees and Shrubs. Cornell University Cooperative Extension.

Liu, Weiping, Wei Zheng, Yun Ma, and Kevin K. Liu. 2006. Sorption and Degradation of Imidacloprid in Soil and Water. Journal of Environmental Science and Health Part B 41 (5): 623-634.

M. Garbelotto, M., Schmidt, and Harnik. 2007. Phosphite Injections and Bark Application of Phosphite + Pentrabark ${ }^{\mathrm{TM}}$ Control Sudden Oak Death in Coast Live Oak.

Matthew Fossen, Ph.D. 2006. Environmental Fate of Imidacloprid. CA Department of Pesticide Regulation.

McClure, M. 1987. Hemlock Woolly Adelgid May Also Attack Spruce. Frontiers of Plant Science - Connecticut Agricultural Experiment Station (USA).

McClure, M. S. 1991. Density-Dependent Feedback and Population Cycles in Adelges tsugae (Homoptera: Adelgidae) on Tsuga canadensis. Environmental Entomology 20 (1): 25864.

McClure, Mark s. 1987. Biology and Control of Hemlock Woolly Adelgid. Vol. 851. Connecticut Agricultural Experiment Station New Haven, CT.

McClure, Mark S., and CASJ Cheah. 2002. Important Mortality Factors in the Life Cycle of Hemlock Woolly Adelgid Adelges tsugae Annand (Homoptera: Adelgidae) in the Northeastern United States. In Proceedings: Hemlock Woolly Adelgid in the Eastern United States Symposium, New Brunswick, NJ Edited by RC Reardon, BP Onken, and J. Lashomb. New Jersey Agricultural Experiment Station, New Brunswick, NJ, USA, 1322.

McCullough, Deborah G., Therese M. Poland, Andrea C. Anulewicz, Phillip Lewis, and David Cappaert. 2011. Evaluation of Agrilus planipennis (Coleoptera: Buprestidae) Control 
Provided by Emamectin Benzoate and Two Neonicotinoid Insecticides, One and Two Seasons After Treatment. Journal of Economic Entomology 104 (5): 1599-1612.

Norris, Dale M. 1967. Systemic Insecticides in Trees. Annual Review of Entomology 12 (1): $127-48$.

Natural Resources Conservation Service. 2017. Web Soil Survey. 2017. https://websoilsurvey.sc.egov.usda.gov

New York Department of Environmental Conservation. 2015. Long Island Pesticide Pollution Prevention Strategy. New York Department of Environmental Conservation.

Onken, Brad P., and Richard C. Reardon. 2011. An Overview and Outlook for Biological Control of Hemlock Woolly Adelgid. ImplementatIon and Status of Biological Control of the Hemlock Woolly AdelgId, 222.

Pesticide Fact Sheet: Dinotefuran. 2004. United States EPA. https://nepis.epa.gov/

Pielou, D. P. 1961. The Control of the Apple Aphid on Dwarf Apple Trees with Bark Applications of Dimethoate. Canadian Journal of Plant Science 41 (2): 407-12.

Rainbow Treecare Scientific. 2012. Xytect WSP Product Label.

Raupp, Michael J., Ralph E. Webb, Adrianna Szczepaniec, Donald Booth, and Robert Ahern. 2004. Incidence, Abundance, and Severity of Mites on Hemlocks Following Applications of Imidacloprid. Journal of Arboriculture 30 (2): 108-113.

Rhea, James R. 1995. Preliminary Results for the Chemical Control of Hemlock Woolly Adelgid in Ornamental and Natural Settings. In The First Hemlock Woolly Adelgid Review, 113125. USDA Forest Service.

Schatz, Anna Lottie. 2017. Accounting for Concentrated and Area Sources of Imidacloprid in Groundwater, Suffolk County, Long Island, NY. M.S., United States -- New York: Cornell University. 
Simon-Delso, Noa, Vanessa Amaral-Rogers, Luc P. Belzunces, Jean-Marc Bonmatin, Madeleine Chagnon, Craig Downs, Lorenzo Furlan, et al. 2015. Systemic Insecticides (Neonicotinoids and Fipronil): Trends, Uses, Mode of Action and Metabolites. Environmental Science and Pollution Research 22 (1): 5-34.

S.V. Joseph, J.L. Hanula, and S.K. Braman. 2011. Distribution and Abundance of Adelges tsugae (Hemiptera: Adelgidae) Within Hemlock Trees. Journal of Economic Entomology.

Tomizawa Motohiro, and John E. Casida. 2003. Selective Toxicity of Neonicotinoids Attributable to Specificity of Insect and Mammalian Nicotinic Receptors. Annual Review of Entomology 48 (1): 339-364.

Tomizawa Motohiro, and John E. Casida. 2010. Neonicotinoid Insecticides: Highlights of a Symposium on Strategic Molecular Designs. ACS Publications.

U.S. Bureau of Labor Statistics. 2017. Pesticide Handlers, Sprayers, and Applicators, Vegetation. https://www.bls.gov/oes/current/oes373012.htm.

Turcotte, Richard M., Anthony Lagalante, Jonathan Jones, Frank Cook, Thomas Elliott, Anthony A. Billings, and Yong-Lak Park. 2017. Spatial and Temporal Distribution of Imidacloprid Within the Crown of Eastern Hemlock. Journal of Insect Science 17 (1).

Turcotte, Richard M, West Virginia University, and Natural Resources Davis College of Argriculture and Design. 2015. Temporal and Spatial Distribution of Imidacloprid and the Arthropod Fauna Associated with Eastern Hemlock, Tsuga Canadensis (L.) Carrière.

USDA. 2012. "CCD Colony Collapse Disorder."

Young, Rebecca F., Kathleen S. Shields, and Graeme P. Berlyn. 1995. Hemlock Woolly Adelgid (Homoptera: Adelgidae): Stylet Bundle Insertion and Feeding Sites. Annals of the Entomological Society of America 88 (6): 827-835. 


\section{Appendix}

\section{Raw Data}

\begin{tabular}{|c|c|c|c|c|c|c|}
\hline Group & $\operatorname{Diam}(\mathrm{cm})$ & $\mathrm{HT}(\mathrm{m})$ & LCR & olefin (ppb) & imidacloprid (ppb) & Total Cost (\$) \\
\hline Untreated Control \#1 & 19.30 & 9.75 & $90.63 \%$ & 0.0 & 0.0 & - \\
\hline Untreated Control \#2 & 13.46 & 10.73 & $88.35 \%$ & 0.0 & 0.0 & - \\
\hline Untreated Control \#3 & 17.27 & 5.30 & $76.44 \%$ & 0.0 & 0.0 & - \\
\hline Untreated Control \#4 & 7.62 & 3.57 & $87.18 \%$ & 0.0 & 0.0 & - \\
\hline Untreated Control \#5 & 12.19 & 6.49 & $82.16 \%$ & 0.0 & 0.0 & - \\
\hline Untreated Control \#6 & 14.48 & 8.38 & $87.27 \%$ & 0.0 & 0.0 & - \\
\hline Untreated Control \#7 & 10.16 & 5.15 & $94.08 \%$ & 0.0 & 0.0 & - \\
\hline Untreated Control \#8 & 9.91 & 5.82 & $89.01 \%$ & 0.0 & 0.0 & - \\
\hline Soil Injection Low \#1 & 20.83 & 8.84 & $86.21 \%$ & 101.9 & 1088.6 & 1.67 \\
\hline Soil Injection Low \#2 & 18.03 & 10.64 & $85.67 \%$ & 0.0 & 0.0 & 1.47 \\
\hline Soil Injection Low \#3 & 19.05 & 10.52 & $89.57 \%$ & 0.0 & 11.0 & 1.48 \\
\hline Soil Injection Low \#4 & 21.08 & 7.16 & $60.43 \%$ & 0.0 & 26.7 & 1.73 \\
\hline Soil Injection Low \#5 & 8.38 & 4.08 & $91.79 \%$ & 19.5 & 171.6 & 0.84 \\
\hline Soil Injection Low \#6 & 8.89 & 3.99 & $100.00 \%$ & 24.3 & 124.6 & 0.95 \\
\hline Soil Injection Low \#7 & 18.29 & 8.53 & $90.36 \%$ & 40.3 & 239.1 & 1.43 \\
\hline Soil Injection Low \#8 & 10.16 & 8.32 & $76.19 \%$ & 5.4 & 42.4 & 0.95 \\
\hline Soil Injection High \#1 & 22.10 & 10.42 & $80.99 \%$ & 0.0 & 24.1 & 2.83 \\
\hline Soil Injection High \#2 & 19.05 & 10.73 & $86.93 \%$ & 0.0 & 38.7 & 2.51 \\
\hline Soil Injection High \#3 & 10.67 & 5.06 & $85.54 \%$ & 68.8 & 323.7 & 2.20 \\
\hline Soil Injection High \#4 & 16.51 & 8.63 & $92.93 \%$ & 0.0 & 56.7 & 2.49 \\
\hline Soil Injection High \#5 & 16.00 & 8.05 & $92.05 \%$ & 0.0 & 21.5 & 2.44 \\
\hline Soil Injection High \#6 & 16.26 & 10.82 & $88.17 \%$ & 0.0 & 2.9 & 1.80 \\
\hline Soil Injection High \#7 & 7.62 & 5.52 & $97.24 \%$ & 54.9 & 381.8 & 1.24 \\
\hline Soil Injection High \#8 & 18.29 & 10.15 & $78.38 \%$ & 0.0 & 37.9 & 2.41 \\
\hline Bark Low \#1 & 18.54 & 9.05 & $88.89 \%$ & 0.0 & 29.6 & 1.93 \\
\hline Bark Low \#2 & 8.89 & 4.94 & $94.44 \%$ & 0.0 & 52.2 & 1.15 \\
\hline Bark Low \#3 & 17.78 & 9.11 & $84.95 \%$ & 0.0 & 0.0 & 1.66 \\
\hline Bark Low \#4 & 14.73 & 10.45 & $88.34 \%$ & 0.0 & 11.0 & 1.52 \\
\hline Bark Low \#5 & 12.70 & 8.69 & $78.25 \%$ & 21.1 & 88.0 & 1.40 \\
\hline Bark Low \#6 & 8.64 & 2.74 & $94.44 \%$ & 0.0 & 25.4 & 1.14 \\
\hline Bark Low \#7 & 11.94 & 7.89 & $84.56 \%$ & 13.1 & 143.6 & 1.36 \\
\hline Bark Low \#8 & 17.78 & 11.31 & $81.13 \%$ & 0.0 & 6.2 & 1.62 \\
\hline Bark High \#1 & 17.78 & 4.69 & $79.22 \%$ & 0.0 & 5.6 & 2.64 \\
\hline Bark High \#2 & 6.60 & 4.30 & $57.45 \%$ & 0.0 & 76.4 & 1.17 \\
\hline Bark High \#3 & 13.97 & 4.72 & $64.52 \%$ & 0.0 & 0.0 & 2.19 \\
\hline Bark High \#4 & 10.92 & 9.85 & $84.52 \%$ & 16.2 & 88.3 & 1.85 \\
\hline Bark High \#5 & 13.21 & 10.36 & $73.53 \%$ & 0.0 & 42.7 & 2.01 \\
\hline Bark High \#6 & 10.41 & 5.76 & $93.65 \%$ & 0.0 & 5.7 & 1.32 \\
\hline Bark High \#7 & 10.16 & 6.40 & $85.71 \%$ & 19.5 & 81.7 & 1.69 \\
\hline Bark High \#8 & 14.22 & 8.26 & $81.55 \%$ & 19.6 & 50.1 & 2.24 \\
\hline Bark High + Adj. \#1 & 23.62 & 10.42 & $83.33 \%$ & 10.3 & 66.5 & 3.00 \\
\hline Bark High + Adj. \#2 & 7.62 & 3.17 & $80.77 \%$ & 13.6 & 117.1 & 1.20 \\
\hline Bark High + Adj. \#3 & 16.00 & 7.07 & $70.69 \%$ & 0.0 & 63.9 & 2.05 \\
\hline Bark High + Adj. \#4 & 10.16 & 7.92 & $82.69 \%$ & 0.0 & 22.9 & 1.86 \\
\hline Bark High + Adj. \#5 & 14.73 & 9.97 & $81.04 \%$ & 39.0 & 190.2 & 2.28 \\
\hline Bark High + Adj. \#6 & 11.94 & 6.61 & $91.71 \%$ & 0.0 & 38.1 & 1.79 \\
\hline Bark High + Adj. \#7 & 13.97 & 6.55 & $86.05 \%$ & 15.1 & 101.4 & 1.89 \\
\hline Bark High + Adj. \#8 & 11.20 & 8.99 & $91.53 \%$ & 15.9 & 59.6 & 2.74 \\
\hline Bark Low + Adj. \#1 & 20.83 & 10.45 & $88.05 \%$ & 0.0 & 0.0 & 2.25 \\
\hline Bark Low + Adj. \#2 & 7.62 & 4.85 & $93.71 \%$ & 0.0 & 26.8 & 1.07 \\
\hline Bark Low + Adj. \#3 & 6.10 & 3.23 & $100.00 \%$ & 12.5 & 60.3 & 0.94 \\
\hline Bark Low + Adj. \#4 & 15.24 & 8.72 & $82.52 \%$ & 0.0 & 7.7 & 1.76 \\
\hline Bark Low + Adj. \#5 & 14.48 & 10.00 & $85.67 \%$ & 0.0 & 12.7 & 1.71 \\
\hline Bark Low + Adj. \#6 & 21.84 & 10.94 & $72.14 \%$ & 0.0 & 0.0 & 2.44 \\
\hline Bark Low + Adj. \#7 & 15.49 & 2.44 & $90.00 \%$ & 0.0 & 12.6 & 1.76 \\
\hline Bark Low + Adj. \#8 & 17.53 & 9.51 & $85.26 \%$ & 0.0 & 8.3 & 1.98 \\
\hline
\end{tabular}




\section{Treatment \& Weather Data Means}

\begin{tabular}{ccccccc}
\hline Group & N & Imidacloprid $(\mathrm{ppb})$ & Olefin $(\mathrm{ppb})$ & DBH $(\mathrm{cm})$ & LCR $(\%)$ & Cost $(\$)$ \\
\hline UTC & 8 & 0.0 & 0.0 & $13.04 \pm 1.38$ & $86.75 \pm 1.90$ & $0.00 \pm 0.00$ \\
Soil Low & 8 & $213.0 \pm 128.6$ & $23.9 \pm 34.6$ & $15.58 \pm 5.46$ & $85.03 \pm 4.23$ & $0.61 \pm 0.03$ \\
Soil High & 8 & $110.9 \pm 53.3$ & $15.4 \pm 28.8$ & $15.81 \pm 4.63$ & $87.76 \pm 2.20$ & $0.84 \pm 0.07$ \\
Bark Low & 8 & $44.5 \pm 17.3$ & $4.2 \pm 8.1$ & $13.87 \pm 3.97$ & $86.85 \pm 2.05$ & $0.84 \pm 0.03$ \\
Bark High & 8 & $43.8 \pm 12.9$ & $6.9 \pm 9.5$ & $12.16 \pm 3.37$ & $77.50 \pm 4.19$ & $0.78 \pm 0.06$ \\
Bark Low + Pentra-Bark & 8 & $25.0 \pm 8.34$ & $10.4 \pm 12.8$ & $14.89 \pm 5.62$ & $87.16 \pm 2.89$ & $1.06 \pm 0.09$ \\
Bark High + Pentra-Bark & 8 & $84.7 \pm 21.5$ & $1.7 \pm 4.7$ & $15.8 \pm 6.94$ & $83.46 \pm 2.37$ & $0.99 \pm 0.10$ \\
\hline
\end{tabular}

\begin{tabular}{ccccccc}
\hline Month & Year & Max $\left({ }^{\circ} \mathrm{C}\right)$ & Min $\left({ }^{\circ} \mathrm{C}\right)$ & $\begin{array}{c}\text { Rain melted, snow, etc. } \\
(\mathrm{cm})\end{array}$ & $\begin{array}{c}\text { Snow, Ice pellets, hail } \\
(\mathrm{cm})\end{array}$ & $\begin{array}{c}\text { Snow, Ice Pellets, Hail, Ice on Ground } \\
(\mathrm{cm})\end{array}$ \\
\hline 5 & 2017 & 21.34 & 9.14 & 0.09 & 0.00 & 0.00 \\
6 & 2017 & 26.54 & 13.22 & 0.08 & 0.00 & 0.00 \\
7 & 2017 & 27.97 & 16.56 & 0.15 & 0.00 & 0.00 \\
8 & 2017 & 26.43 & 13.82 & 0.06 & 0.00 & 0.00 \\
9 & 2017 & 24.09 & 11.28 & 0.04 & 0.00 & 0.00 \\
10 & 2017 & 20.93 & 6.49 & 0.08 & 0.00 & 0.00 \\
11 & 2017 & 10.00 & -2.07 & 0.05 & 0.15 & 0.00 \\
12 & 2017 & 3.51 & -6.01 & 0.02 & 0.21 & 0.17 \\
1 & 2018 & 1.15 & -10.98 & 0.04 & 0.19 & 0.76 \\
2 & 2018 & 10.02 & -3.58 & 0.13 & 1.18 & 0.41 \\
3 & 2018 & 7.44 & -3.69 & 0.19 & 1.82 & 0.35 \\
4 & 2018 & 14.44 & 1.11 & & & 1.57 \\
\hline
\end{tabular}




\section{Photo Credits}

\begin{tabular}{|c|c|c|c|c|}
\hline \multicolumn{3}{|c|}{ Figure \# Page \# UGA \# } & \multicolumn{2}{|r|}{ Citation } \\
\hline 1 & 4 & - & Global Hemlock Distril & ution Nathan Havill, USDA Forest Service, Northern Research Station \\
\hline 2 & 6 & - & Global HWA Distributi & on $\quad$ Carole Cheah, Connecticut Agricultural Experiment Station \\
\hline 3 & 8 & - & North American Lifecy & Jeffrey Ward, Connecticut Agricultural Experiment Station \\
\hline $4 \mathrm{a}$ & 11 & 5018078 & Eggs & Pennsylvania Department of Conservation and Natural Resources, Bugwood.org \\
\hline $4 b$ & 11 & 5018073 & Crawler & Pennsylvania Department of Conservation and Natural Resources, Bugwood.org \\
\hline $4 c$ & 11 & 5449457 & Crawler Closeup & Kelly Oten, North Carolina Forest Service, Bugwood.org \\
\hline $4 d$ & 11 & 5449456 & Nymph Closeup & Kelly Oten, North Carolina Forest Service, Bugwood.org \\
\hline $4 \mathrm{e}$ & 11 & 5473217 & Multiple Nymphs & Ashley Lamb, Virginia Polytechnic Institute and State University, Bugwood.org \\
\hline $4 \mathrm{f}$ & 11 & & Nymph Stylet & \\
\hline $4 g$ & 11 & 5476127 & Adults & USDA Forest Service Southern Research Station, Bugwood.org \\
\hline $4 \mathrm{~h}$ & 11 & 5449453 & Adult Electron Microsc & ope Kelly Oten, North Carolina Forest Service, Bugwood.org \\
\hline $4 \mathrm{i}$ & 11 & - & Winged Sexupare & Nathan Havill, USDA Forest Service, Northern Research Station \\
\hline $4 \mathrm{j}$ & 11 & - & Fundatrix & Nathan Havill, USDA Forest Service, Northern Research Station \\
\hline 5 & 12 & - & Complete Lifecycle & Nathan Havill, USDA Forest Service, Northern Research Station \\
\hline $6 a$ & 16 & 1276009 & Sassajiscymnus tsugae & Carole Cheah, Connecticut Agricultural Experiment Station, Bugwood.org \\
\hline $6 b$ & 16 & 5017090 & Scymnus sinuanodulus & Pennsylvania Department of Conservation and Natural Resources, Bugwood.org \\
\hline $6 \mathrm{c}$ & 16 & 1276021 & Laricobius nigrinus & Ashley Lamb, Virginia Polytechnic Institute and State University, Bugwood.org \\
\hline 7 & 21 & - & Metabolic Pathway & F. J. Placke \\
\hline 8 & 25 & - & Chemical Properties & Matthew Fossen, California Department of Pesticide Regulation \\
\hline 9 & 27 & - & Toxicity Ratings & Matthew Fossen, California Department of Pesticide Regulation \\
\hline $10 \mathrm{a}$ & 29 & - & Height Limitations & Matt Quinterno \\
\hline $10 \mathrm{~b}$ & 29 & - & Spray Drift & Matt Quinterno \\
\hline $10 \mathrm{c}$ & 29 & 796066 & Pesticide Drift & Larry R. Barber, USDA Forest Service, Bugwood.org \\
\hline $11 \mathrm{a}$ & 30 & - & Soil Drench & Matt Quinterno \\
\hline $11 \mathrm{~b}$ & 30 & - & Calibrated Soil Probe & Rainbow Treecare Scientific \\
\hline $11 \mathrm{c}$ & 30 & 1344053 & Kioritz & Great Smoky Mountains National Park Resource Management, USDI National \\
\hline Park & rvice & ugwood.o & & \\
\hline $11 d$ & 30 & - & Motorized Backpack & Rainbow Treecare Scientific \\
\hline $11 \mathrm{e}$ & 30 & - & Bottle Pump & Matt Quinterno \\
\hline $12 \mathrm{a}$ & 31 & 5005031 & Mauget Capsule & Ronald F. Billings, Texas A\&M Forest Service, Bugwood.org \\
\hline $12 b$ & 31 & - & Arborjet Injector & Arborjet \\
\hline $12 \mathrm{c}$ & 31 & - & Wedgel Injector & Arborsystems \\
\hline 13 & 32 & - & Backpack Sprayer & Matt Quinterno \\
\hline 14 & 39 & - & Application Equipment & Matt Quinterno \\
\hline
\end{tabular}


